\title{
Integrin-Linked Kinase (ILK) Deletion Disrupts Oligodendrocyte Development by Altering Cell Cycle
}

\author{
Rashad Hussain and Wendy B. Macklin \\ Department of Cell and Developmental Biology, University of Colorado School of Medicine, Aurora, Colorado 80045
}

During development, oligodendrocytes are initially specified, after which oligodendrocyte precursor cells (OPCs) migrate and proliferate before differentiating into myelinating cells. Lineage-specific programming of oligodendrocytes results from sensing environmental cues through membrane-bound receptors and related intracellular signaling molecules. Integrin-linked kinase (ILK) is an important protein that is expressed at the inner margins of the plasma membrane and can mediate some of these signals. The current studies demonstrate that ILK deletion reduces the proliferation and differentiation of OPCs in the developing CNS. There was a significant decrease in the number of OPCs and mature oligodendrocytes throughout postnatal development in Olig1Cre ${ }^{+/-} \times \mathrm{ILK}^{\mathrm{fl} / \mathrm{fl}}$ mice. These changes were accompanied by reduced numbers of myelinated axons. Key proteins involved in cell cycle regulation were dysregulated. Cyclin D1/D3 and cyclin-dependent kinase 2/4 (cdc2/cdc4) were downregulated and the cell cycle inhibitor protein p27 Kip1 was upregulated. Therefore, ILK deletion impaired the developmental profile, proliferation, and differentiation of OPCs by altering the expression of regulatory cytoplasmic and nuclear factors.

Key words: cell cycle; myelin; oligodendrocyte progenitor cell

\section{Significance Statement}

Integrin-linked kinase (ILK) is a scaffolding protein involved in integrating signals from the extracellular environment and communicating those signals to downstream effectors within cells. It has been proposed to regulate aspects of oligodendrocyte process extension and thereby myelination. However, the current studies demonstrate that it has an earlier impact on cells in this lineage. Knocking down ILK in Olig1-Cre-expressing cells reduces the pool of oligodendrocyte progenitor cells (OPCs). This smaller pool of OPCs results from altered cell cycle and reduced cell proliferation. These cells myelinate fewer axons than in wild-type mice and, in corpus callosum, the myelin is thinner than in controls. Interestingly, the smaller pool of spinal cord oligodendrocytes generates myelin that is of normal thickness.

\section{Introduction}

Myelination constitutes an evolutionary step of clear functional value. Axonal ensheathment by Schwann cells in the PNS and oligodendrocytes in the CNS is crucial for rapid action potential conduction. Numerous molecules and growth factors have been described that influence myelination and remyelination positively or negatively (Emery, 2010; Nave, 2010; Franklin et al.,

\footnotetext{
Received July 1, 2016; revised Oct. 28, 2016; accepted Nov. 15, 2016.

Author contributions: R.H. and W.B.M. designed research; R.H. performed research; R.H. and W.B.M. analyzed data; R.H. and W.B.M. wrote the paper.

This work was supported by the National Multiple Sclerosis Society and the National Institutes of Health (Grant NS082203). We thank Drs. Reinhard Faessler and Stijn de Langhe for the ILK ${ }^{\mathrm{f} / \mathrm{fl}}$ mice and Dr. Jennifer Bourne for technical assistance in electron microscopy.

The authors declare no competing financial interests.

Correspondence should be addressed to Wendy B. Macklin, Department of Cell and Developmental Biology, University of Colorado School of Medicine, Mail Stop 8108, 12801 East $17^{\text {th }}$ Avenue, Aurora, C0 80045. E-mail: Wendy.macklin@ucdenver.edu.

DOI:10.1523/JNEUROSCI.2113-16.2016

Copyright $\odot 2017$ the authors $\quad 0270-6474 / 17 / 370397-16 \$ 15.00 / 0$
}

2012; Zuchero and Barres, 2013; McKenzie et al., 2014; Fields, 2015; Tsai et al., 2016) and act through a number of known transcription factors (Emery et al., 2009; Zhu et al., 2012; Bujalka et al., 2013; Hornig et al., 2013; Yu et al., 2013; Silbereis et al., 2014). The pathways connecting these extracellular signals with the transcriptional changes in oligodendrocytes are still being investigated (Colognato and Tzvetanova, 2011; Ahrendsen and Macklin, 2013; Wood et al., 2013; Bercury and Macklin, 2015; Gaesser and Fyffe-Maricich, 2016). Integrin-linked kinase (ILK) is a multifunctional intracellular effector of cell-matrix interactions that regulates many cellular processes (Hannigan et al., 1996; Persad et al., 2000; Koul et al., 2005; Chiswell et al., 2008; McDonald et al., 2008a; Dagnino, 2011; Widmaier et al., 2012). However, its role in oligodendrocyte precursor cells (OPCs) is less clear. ILK was originally defined as a binding partner of integrin $\beta 1$ and is well known for its dual actions, both as a scaffolding molecule (Chiswell et al., 2008; Dagnino, 2011) and as a serine/threonine protein kinase (Berken et al., 2003; Troussard et al., 2003; Okamura et al., 2007; Watzka et al., 2011). It modulates 
many downstream activators, in part by phosphorylating Akt, glycogen synthase kinase (GSK) $3 \beta$, and myosin light chain (Novak and Dedhar, 1999; Persad et al., 2000; Grashoff et al., 2003).

The phosphatidylinositol-3-kinase (PI3K)/Akt signaling axis has a strong impact on oligodendrocyte development and myelination (Flores et al., 2008; Norrmén and Suter, 2013; Gaesser and Fyffe-Maricich, 2016) and the intracellular localization of ILK is quite strategic in this axis; it is downstream of PI3K but upstream of AKT, phosphorylating Akt at Serine 473 (Koul et al., 2005; Xie et al., 2013). ILK is essential during PNS development (Pereira et al., 2009), but its role in CNS myelination is less clear. Oligodendrocyte process extension and differentiation in vitro requires ILK (Chun et al., 2003), which acts via Rho-GTPase to regulate the actin cytoskeleton and oligodendrocyte growth cones (O'Meara et al., 2013; Michalski et al., 2016). In other cells, in addition to its cytoskeletal role, ILK is involved in cell replication and oncogenesis (McDonald et al., 2008a; McDonald et al., 2008b; Fielding et al., 2011). We investigated such effects of ILK during oligodendrocyte development and established that some compensation for its role in the actin cytoskeleton occurs in oligodendrocytes because myelination does occur. However, a major effect of ILK loss in oligodendrocytes is a significant reduction in the number of oligodendrocytes and a resulting reduction in the number of myelinated axons. One of the most unique observations is the fact that loss of ILK alters the cell cycle in oligodendrocytes.

\section{Materials and Methods}

Transgenic animals. Olig1-Cre (B6;129S4-Olig1tm1(Cre)Rth/J; Jackson Laboratories, Lu et al., 2002) mice were crossed to homozygous ILK ${ }^{\text {fl/fl }}$ mice (Grashoff et al., 2003) to produce neural precursor-cellspecific deletion of ILK termed as Olig1Cre ${ }^{+/-} \times \mathrm{ILK}^{\mathrm{fl} / \mathrm{fl}}($ ILK cKO; Fig. 1A). The transgenic mice PLP-EGFP-3'UTR (Mallon et al., 2002) were also crossed with Olig1Cre ${ }^{+/-} \times \mathrm{ILK}^{\mathrm{fl} / \mathrm{fl}}$ to produce triple transgenic mice Olig $1 \mathrm{Cre}^{+/-} \times \mathrm{ILK}^{\mathrm{fl} / \mathrm{fl}} \times \mathrm{PLP}^{+\mathrm{EGFP}}{ }^{+/-}$for further study/identification of the oligodendrocyte lineage. Genotypes were determined by PCR (Lu et al., 2002; Mallon et al., 2002; Grashoff et al., 2003). All mouse breeding and experimental procedures were performed in an Association for Assessment and Accreditation of Laboratory Animal Care-accredited facility in accordance with the National Institutes of Health's Guide for the Care and Use of Laboratory Animals and approved by University of Colorado Denver Institutional Animal Care and Use Committee.

Perfusion/fixation and tissue processing. Transgenic pups ( $n=86,46$ males and 40 females collected at different time points) were anesthetized and perfused transcardially with $4 \%$ paraformaldehyde (PFA). Brains and spinal cords were dissected out and postfixed in the same fixative overnight, followed by cryoprotection with $30 \%$ sucrose and blocked in OCT (Sakura Finetek). Sections $(30 \mu \mathrm{m})$ were cut by cryostat (Leica CM1950), permeabilized with $0.3-1 \%$ Triton X-100 for 30 min, blocked with $5 \%$ normal donkey serum (NDS) for $1 \mathrm{~h}$, and incubated with monoclonal or polyclonal primary antibodies for $2 \mathrm{~h}$ at room temperature or overnight at $4^{\circ} \mathrm{C}$ when necessary.

Secondary antibodies (Jackson ImmunoResearch Laboratories) were either fluorescently conjugated or biotinylated (for DAB reaction or streptavidin reaction) and diluted in 5\% NDS-PBS, 0.3\% Triton X-100. The incubation time ranged from 60 to $90 \mathrm{~min}$ at room temperature. Section/slides were counterstained for nuclei using Hoechst 33342 (1: 100,000, PK-CA707-40046; Promo Kine) for 5 min and mounted with Fluoromount-G (Southern Biotech).

Mixed glia- and oligodendrocyte-enriched culture. Rat oligodendrocytes were prepared by standard protocols (Dai et al., 2014). Mouse mixed glia cultures and oligodendrocyte-enriched cultures were prepared as described by Dai et al. (2014) and O'Meara et al. (2013). Briefly, neonatal mice brains were dissected and dissociated to single cells mechanically and enzymatically. Cells were plated (one brain per flask) in poly-Dlysine-precoated flasks and cultured for $9 \mathrm{~d}$. OPCs were purified by shaking overnight.

Detached cells were plated in precoated chamber slides/tissue culture dishes with poly-D-lysine $(10 \mu \mathrm{g} / \mathrm{ml})$, laminin $(10 \mu \mathrm{g} / \mathrm{ml})$, and fibronectin $(10 \mu \mathrm{g} / \mathrm{ml})$. Plating density ranged from 10,000 to 15,000 cells per chamber in eight-chamber slides. Cells were grown in serum-free oligodendrocyte proliferation and differentiation medium supplemented with insulin $(5 \mu \mathrm{g} / \mathrm{ml})$, GlutaMax $(10 \mu \mathrm{l} / \mathrm{ml})$, holo-transferrin $(50 \mu \mathrm{g} /$ $\mathrm{ml})$, B27 $(20 \mu \mathrm{l} / \mathrm{ml})$, fetal bovine serum $(0.5 \%)$, ciliary neurotropic factor $(50 \mathrm{ng} / \mathrm{ml})$, platelet-derived growth factor $(10 \mathrm{ng} / \mathrm{ml})$, and fibroblast growth factor $(10 \mathrm{ng} / \mathrm{ml})$.

Rat oligodendrocyte-enriched cultures were treated with DMSO or ILK inhibitor (cpd22; Millipore). Mouse PLP-EGFP and ILK cKO $\times$ PLP-EGFP cultures were analyzed for cell number and proliferation dynamics. After treatment, cells were fixed with 4\% PFA for $30 \mathrm{~min}$ and stained for immunohistological markers.

Immunohistochemistry. The following antibodies were used: for myelin and mature oligodendrocytes, mouse anti-CC1 (1:300, \#OP80; Calbiochem) and mouse anti-MBP (1:1000 \#SMI94; Covance). For neural/ OPCs, guinea pig anti-NG2 (1:500, kind gift from Dr. William Stallcup, Burnham Institute), rabbit anti-PDGFR $\alpha$ (1:2000, \#sc-338; Santa Cruz Biotechnology), rabbit anti-Olig2 (1:10,000, kind gift from Dr. Charles Stiles, Harvard University), rabbit anti-Sox2 (1:1000, \#AB5603; Millipore), and goat anti-Sox10 (1:1000, \#sc-17342; Santa Cruz Biotechnology). For neurons, mouse anti-NeuN (1:1000, \#MAB 377, EMD Millipore) and chicken anti-neurofilament (1:2000, \#CH22104; Neuromics). For astrocytes, mouse anti-GFAP (1:600, \#G3898; SigmaAldrich). For ILK and other signaling molecules; rabbit anti-pS6RP (1: 1000, \#22115; Cell Signaling Technology), rabbit anti-p-AKT (ser 473, 1:1000, \#9271; Cell Signaling Technology), rabbit anti-ILK (1:500, \#3856S; Cell Signaling Technology), rabbit anti-Cyclin D1 (1:700, mAb \#2978; Cell Signaling Technology), mouse anti-cyclin D3 (1:700, mAb 2936; Cell Signaling Technology), rabbit anti-cyclin-dependent kinase 2 (1:700, CDK2, mAB2546; Cell Signaling Technology), rabbit anti-cyclindependent kinase 4 (1:700, CDK4, mAb12790; Cell Signaling Technology), and rabbit anti-p27 Kip1 (1:500, mAb3686; Cell Signaling Technology). Proliferating cell labeling was done using nuclear marker Ki67 (1:700, \#15580; Abcam).

Western blot. Neural tissue (taken from $n=6$ pups, all males, control $=3, \mathrm{KO}=3)$ was homogenized in RIPA buffer $(25 \mathrm{~mm}$ Tris- $\mathrm{HCl}$, pH 7.5, $150 \mathrm{~mm} \mathrm{NaCl}, 1 \mathrm{~mm}$ EDTA, 1\% NP-40, 0.1\% SDS, 0.1\% DOC, R0278; Sigma-Aldrich) supplemented with protease inhibitor (complete mini, \#04693124001; Roche) and phosphatase inhibitor (\#524625; Calbiochem). Proteins were quantified by Pierce Bicinchoninic Acid Protein Assay (\#23227; Thermo Scientific). Samples were prepared and analyzed by standard SDS PAGE protocols. Proteins were transferred onto polyvinylidene fluoride membrane, blocked for $1 \mathrm{~h}$ with 5\% BSA in Trisbuffered saline with Tween 20, and incubated with primary antibodies overnight. Primary antibodies used were rabbit anti-GAPDH (1:5000, \#5174S; Cell Signaling Technology), mouse anti- $\beta$-Actin (1:5000, \#3700S; Cell Signaling Technology), rabbit anti-total mTOR (1:1000, \#4517S; Cell Signaling Technology), rabbit anti-p-mTOR ser 2448 (1: 1000, \#2971L; Cell Signaling Technology), rabbit anti-p-mTOR ser 2481 (1:1000, \#2974; Cell Signaling Technology), rabbit anti-Raptor (1:1000, \#2280; Cell Signaling Technology), rabbit anti-Rictor (1:1000, \#2114; Cell Signaling Technology), rabbit anti-G $\beta L$ (1:1000, \#3274; Cell Signaling Technology), rabbit anti-t-AKT (1:1000, \#2920S; Cell Signaling Technology), rabbit anti-p-AKT473 (1:1000, \#4060L; Cell Signaling Technology), rabbit anti-p-AKT308 (1:1000,\#9275; Cell Signaling Technology), rabbit anti-PTEN ser 380 (1:1000, \#9551; Cell Signaling Technology), rabbit anti-p-GSK-3 $\beta$ ser 9 (1:1000, \#5558; Cell Signaling Technology), rabbit anti-total-GSK-3 $\beta(1: 1000$, \#9315; Cell Signaling Technology), ILK (1:1000, \#3856S; Cell Signaling Technology), and rabbit anti-t-S6RP (1:1000, \#9202; Cell Signaling Technology), p-S6RP ser 235/236 (1:1000, \#2211; Cell Signaling Technology), rabbit anti-p-S6RP ser 240/244 (1:1000, \#2215; Cell Signaling Technology), rabbit anti-pp70S6 kinase (1:1000, \#9234; Cell Signaling Technology), rabbit antiphospho-4E-BP1 (Thr37/46) (1:500, \#2855; Cell Signaling Technology), 
A

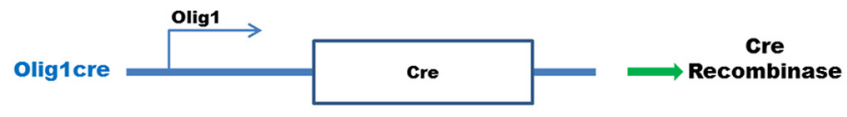

ILK fl/fI

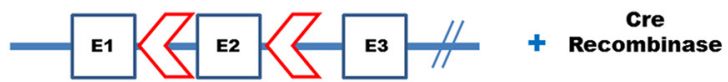

C

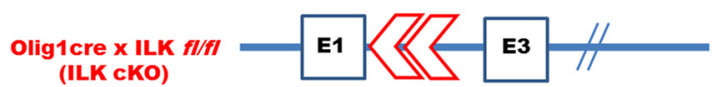

B

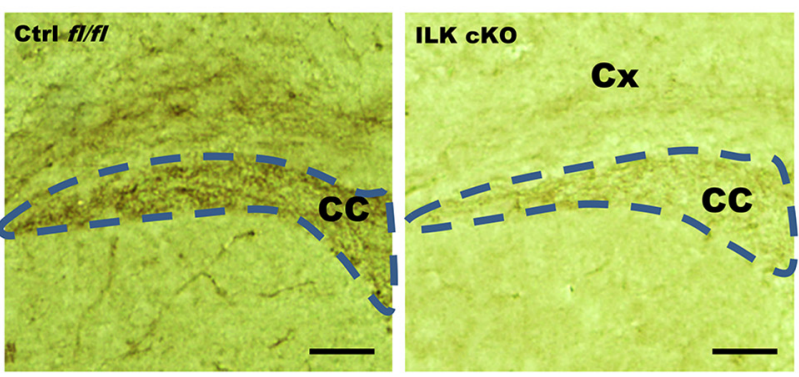

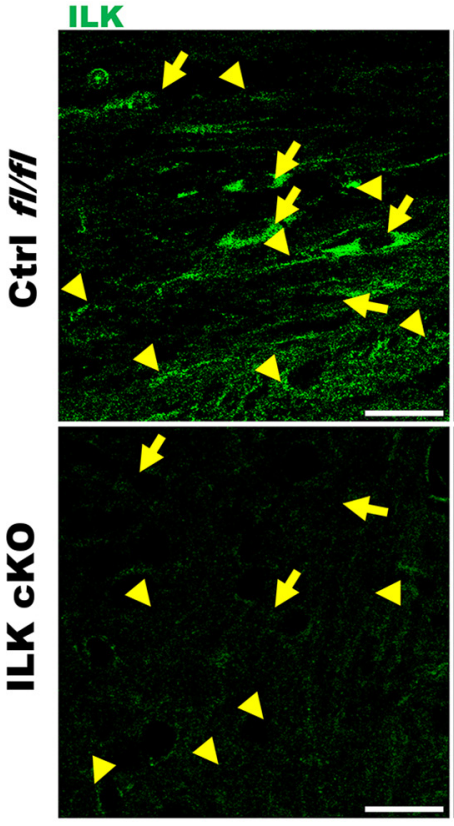

D

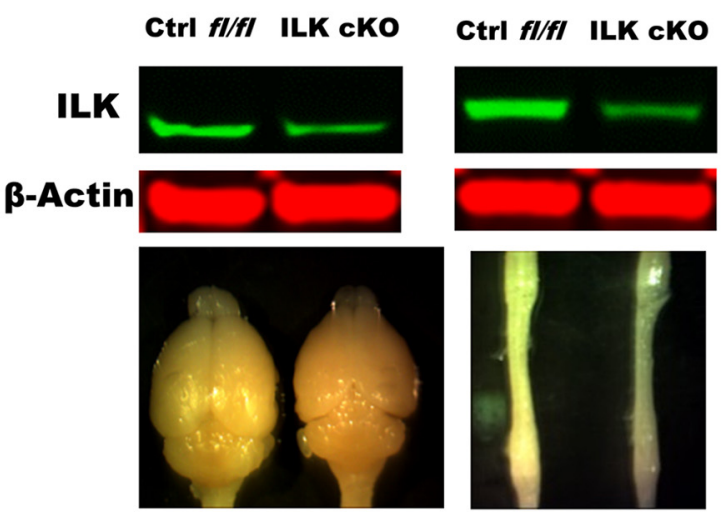

C.C1
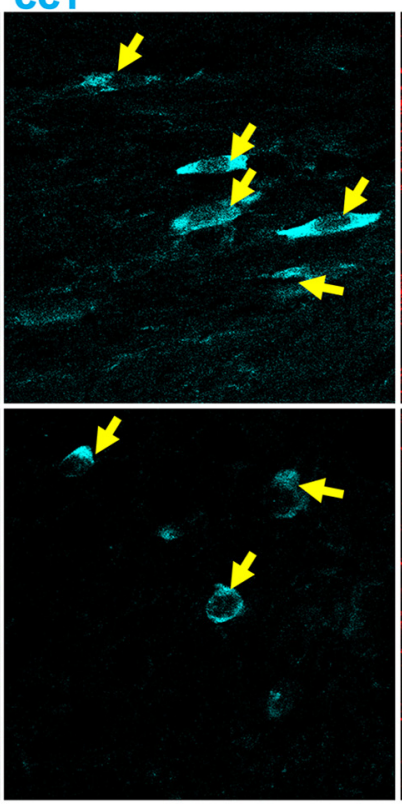

NG2

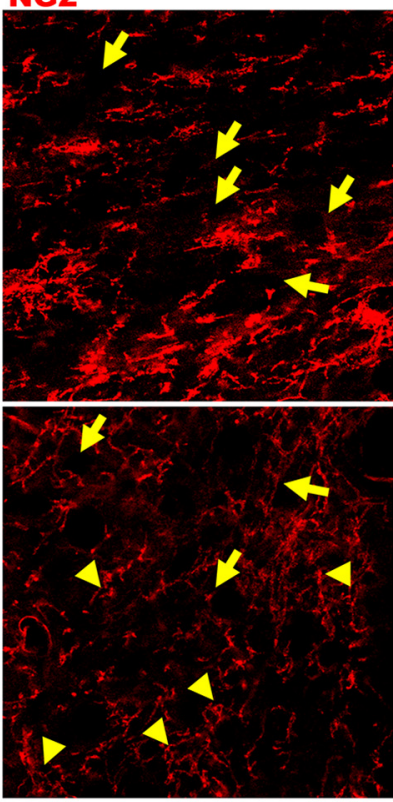

ILK/CC1/NG2

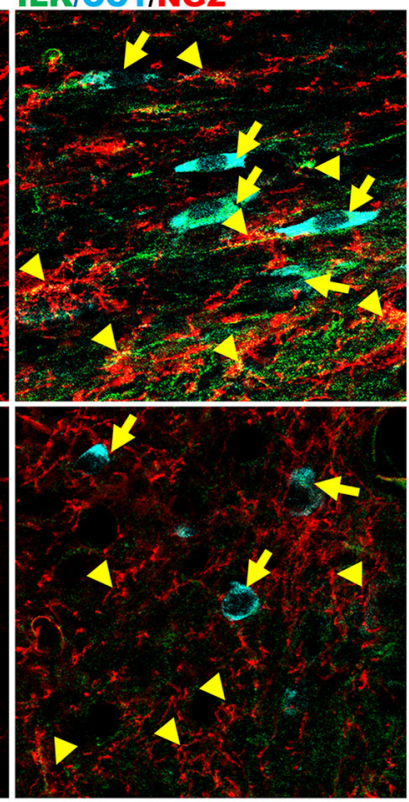

E

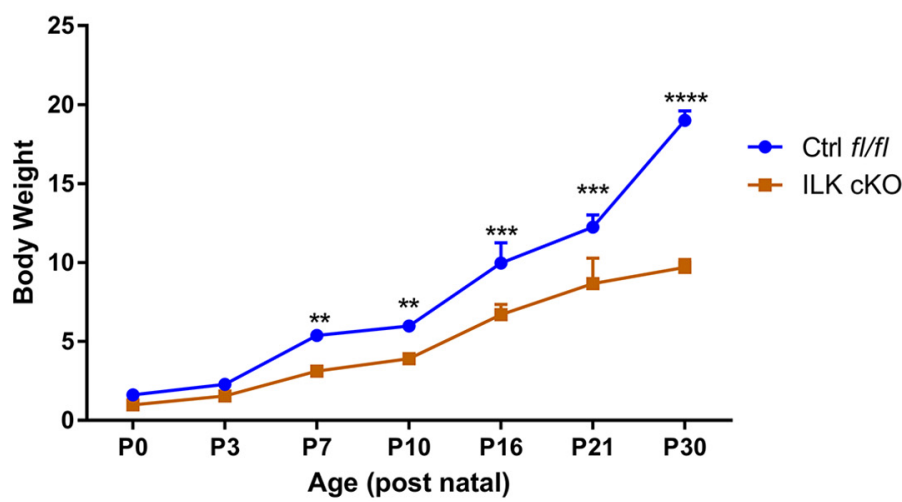

Figure 1. ILK deletion in 0lig1-lineage cells. ILK ${ }^{\mathrm{fl} / \mathrm{fl}}$ mice (two LoxP sites [red arrows] flanking exon 2) were crossed with Olig1-Cre mice to generate Olig 1-Cre $\times I L K^{\mathrm{fl} / f \mathrm{l}}$ mice (ILK cK0 mice; $\boldsymbol{A}$ ). In P10 sagittal sections from control fl/fl mice, ILK was detected in corpus callosum (CC) and cortex (CX), but ILK expression was reduced in comparable regions of ILK cKO brains (B). In control fl/fl mice, ILK was detected in C(1+ oligodendrocytes (arrows), to a lesser extent in NG2+ OPCs (arrowheads), and deletion was evident in CC1+ and NG2+ oligodendrocytes in ILK cKO mice (C). At P0, there was reduced ILK in Western blots of brains and spinal cords from ILK cKO mice and, by P21, these mice had noticeably smaller brain size and thin transparent spinal cords (D). ILK cKO pups were significantly smaller in body weight/size than control fl/fl pups at all stages of postnatal development. Data (4-7 animals/group) were subjected to analysis for mean \pm SEM, two-way ANOVA, followed by Sidak's multiple-comparison test using GraphPad Prism software $(\boldsymbol{E}) .{ }^{* *} p<0.01,{ }^{* * *} p<0.001,{ }^{* * * *} p<$ 0.0001. Scale bars: $B, 50 \mu \mathrm{m} ; \boldsymbol{C}, 20 \mu \mathrm{m}$. 
A

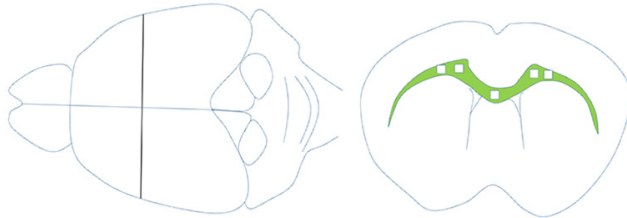

B

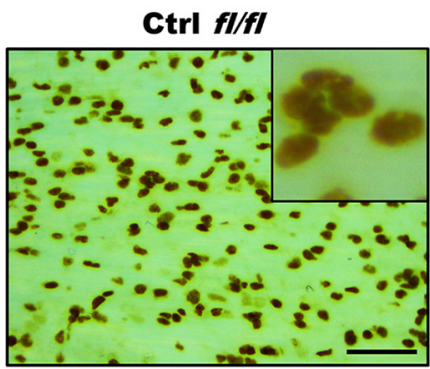

D

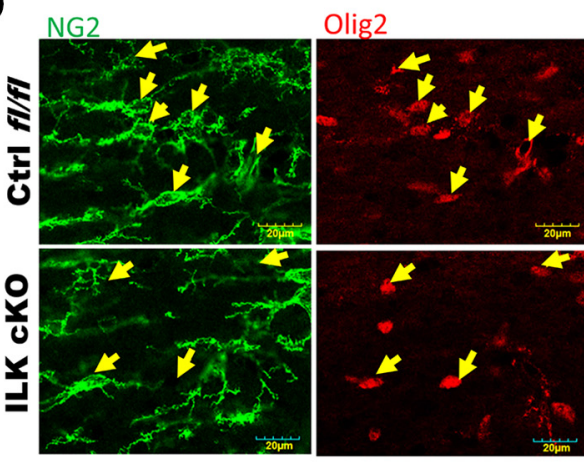

E

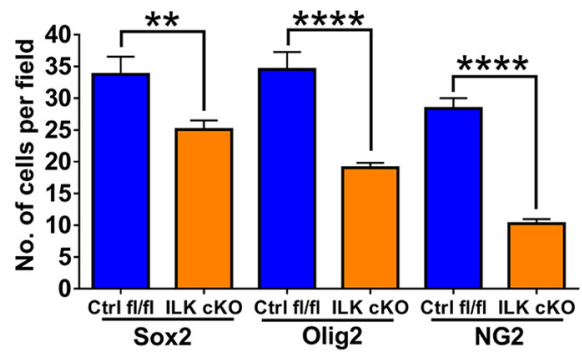

G

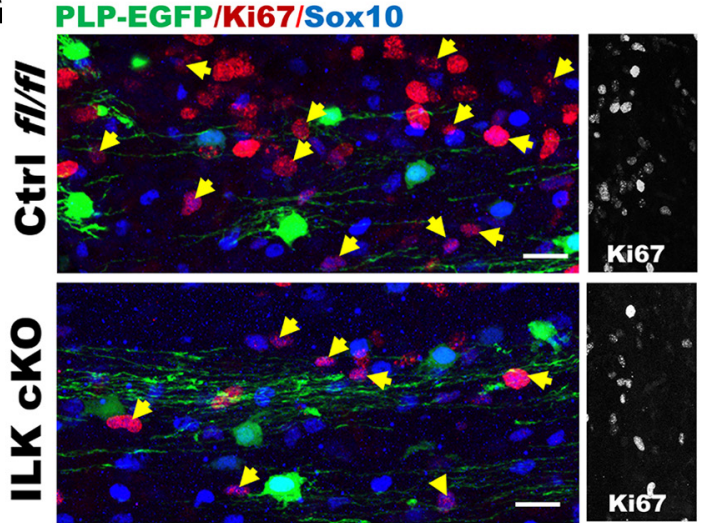

ILK cKO

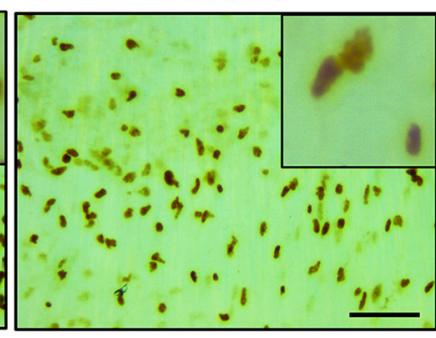

Sox 2
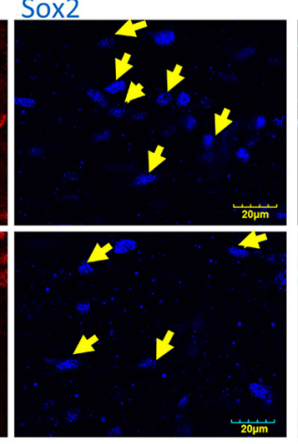

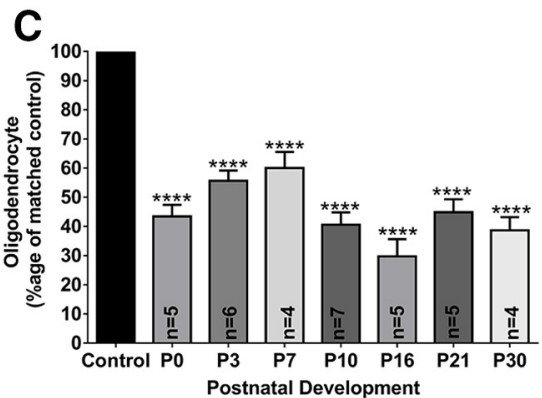

NG2/Olig2/Sox2/Hoechst

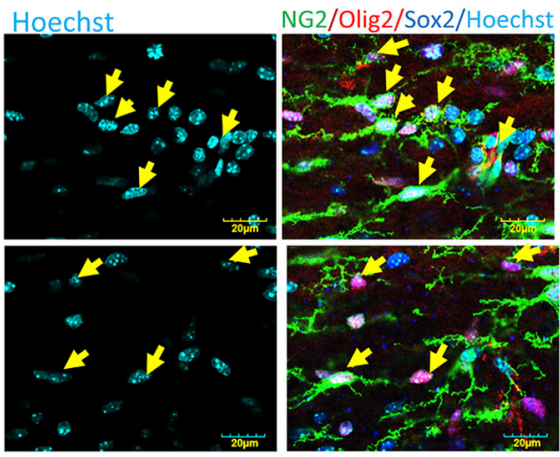

$\mathbf{F}$

H
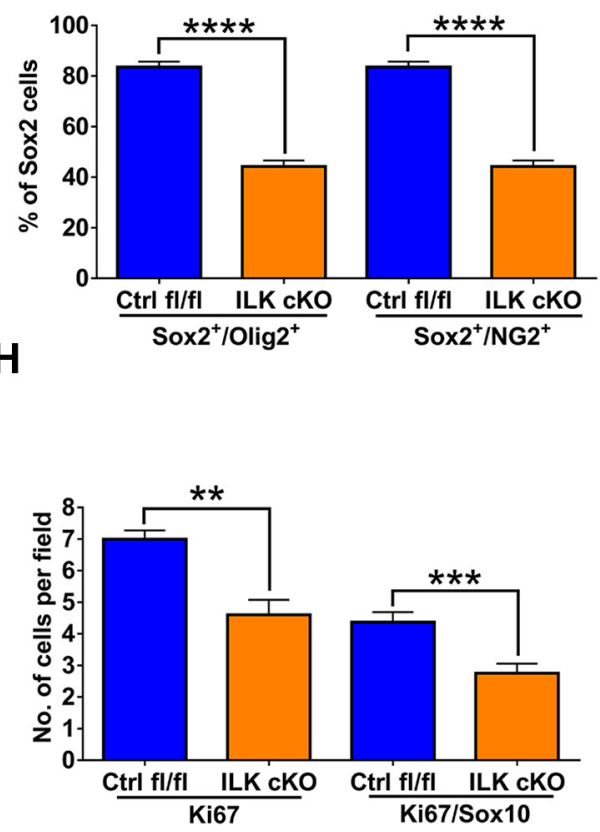

Figure 2. ILK deletion resulted in a dramatic decrease in the number of oligodendrocyte lineage cells and reduced proliferation. The number of Olig2 + cells was counted in different regions of corpus callosum (boxes within corpus callosum in $\boldsymbol{A}$ ) from P0 to P30 and they were significantly reduced (**** $<0.0001$ ) in ILK cK0 pups compared with control pups through development ( $\boldsymbol{B}, \boldsymbol{C}$ ). ILK deletion also appeared to reduce Olig2 intensity in cells at P10 (B). Cells expressing NG2 (green), Olig2 (red), Sox2 (blue), or Hoechst (cyan; $\boldsymbol{D}$ ) were quantified in P0 midline corpus callosum and a significant decrease in the number of Sox $2+\left({ }^{* *} p<0.01\right)$, 0lig2 $+\left({ }^{* * * *} p<0.0001\right)$, and NG2 $+\left({ }^{* * * *} p<0.0001\right)$ cells was noted (E). The percentage of Sox2 + cells expressing 0 lig2 or NG2 was quantified and these was significantly $\left({ }^{* * * *} p<0.0001\right)$ downregulated in ILK cKO pups $(\boldsymbol{F})$. At P10, proliferating cells were identified by Ki67 (red) expression $(\boldsymbol{G})$ and a significant $\left.{ }^{* * *} p<0.01\right)$ decrease in Ki67 was seen $(\boldsymbol{H})$, particularly in OPCs expressing transcription factor Sox10 (blue; $\mathrm{G}-\mathrm{H}_{,}{ }^{* * *} p<0.001$ ). Data (4-7 animals/ group; $2-4$ sections with multiple counting regions of interest per animal) were analyzed; group means were compared using two-way ANOVA, bar charts are presented as mean \pm SEM using GraphPad Prism software. ${ }^{* *} p<0.01,{ }^{* * *} p<0.001$, **** $p<0.0001$. Scale bars: $\boldsymbol{B}, 50 \mu \mathrm{m} ; \boldsymbol{D}, \mathbf{G}, 20 \mu \mathrm{m}$. 
A

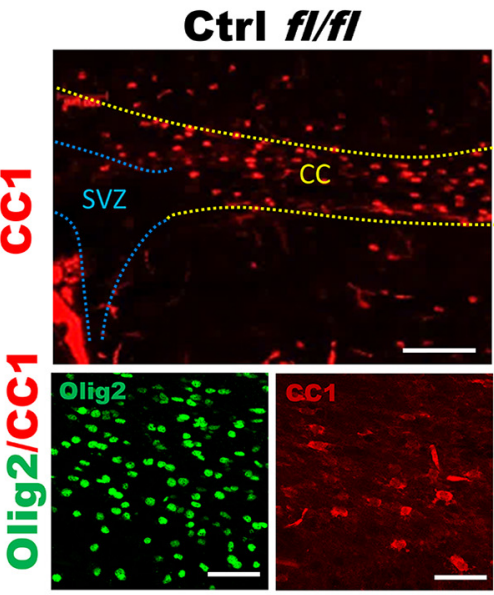

E

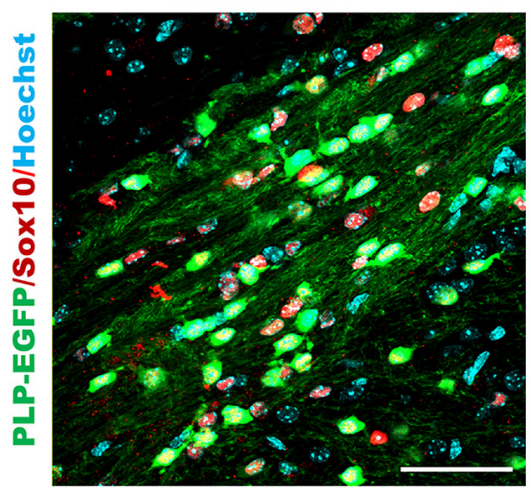

$\mathbf{F}$

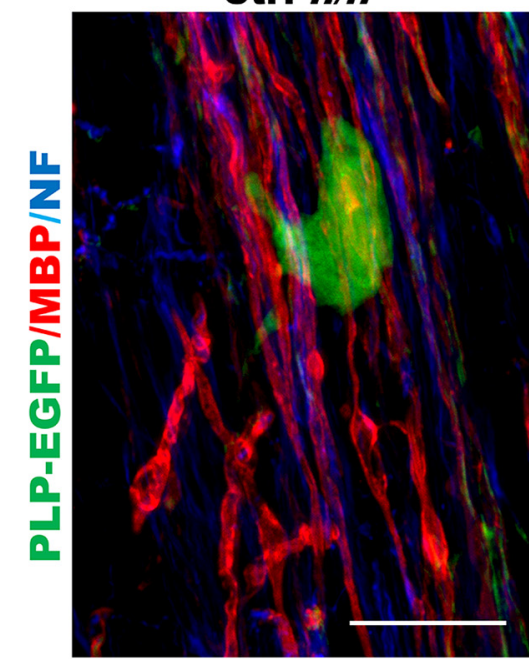

ILK cKO

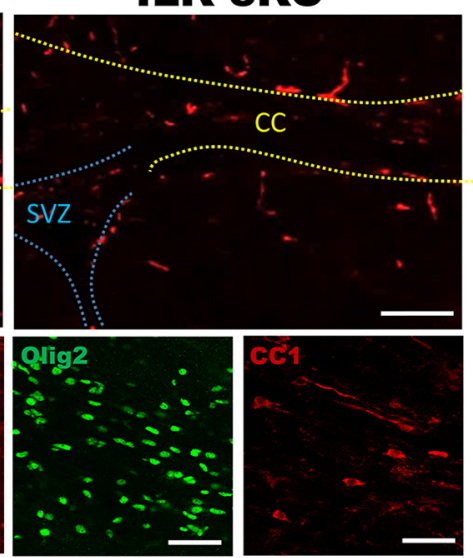

B

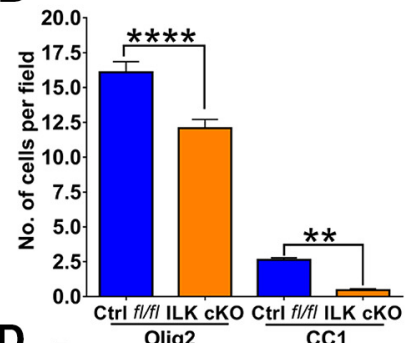

D

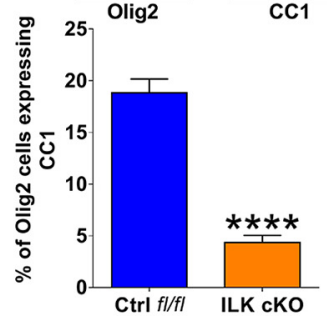

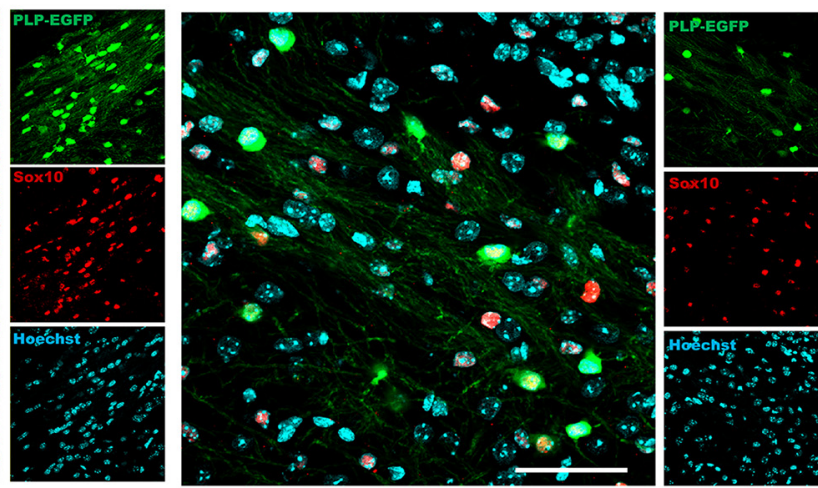

ILK cKO

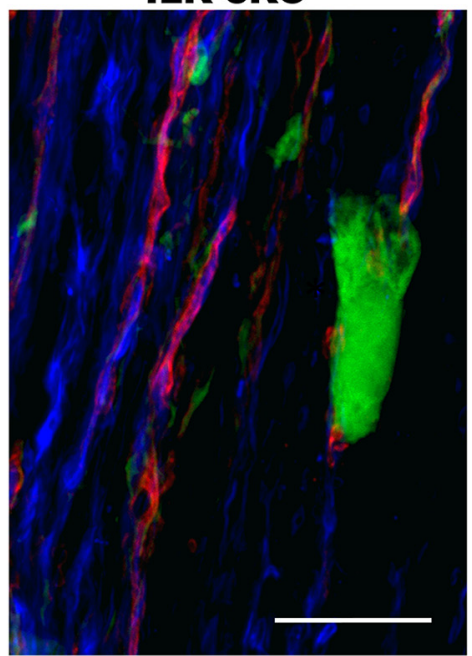

G

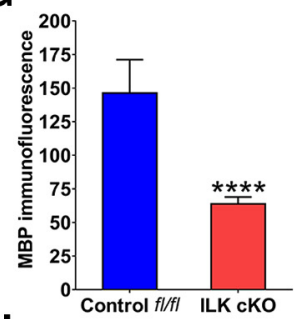

H

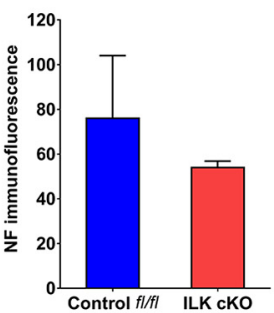

Figure 3. ILK CK0 mice had reduced mature oligodendrocytes. By P10, the number of total oligodendrocytes (0lig2 +$)$ and mature oligodendrocytes $(C C 1+)$ was reduced $(* * * * p<0.0001$ and ${ }^{* *} p<0.01$, respectively) in the corpus callosum in ILK CKO mice $(\boldsymbol{A}, \boldsymbol{B})$. The percentage of Olig2 cells that were $C\left(1+\right.$ was reduced to an even greater extent $\left({ }^{* * * *} p<0.0001\right)$ than total cells in ILK cKO pups $(\boldsymbol{C}, \boldsymbol{D})$. Deletion of ILK resulted in decreased PLP-EGFP (green)/Sox10 (red) cells in corpus callosum of P10 ILK cKO $\times$ PLP-EGFP pups (E). Transverse sections of brain derived from control $\mathrm{fl} / \mathrm{fl} \times \mathrm{PLP}$-EGFP and ILK cKO $\times$ PLP-EGFP were stained for MBP (red) and NF (blue; $\boldsymbol{F})$ and a significant decrease in MBP immunostaining (**** $p<0.0001)$ was observed $(\boldsymbol{G})$, whereas NF staining remained unchanged $(\boldsymbol{H})$. Data were obtained from 5-9 pups/group; multiple $(>3)$ slices were processed. Group means were compared using two-way ANOVA followed by Tukey's multiplecomparisons test $(\boldsymbol{B})$ and unpaired Student's $\boldsymbol{t}$ test $(\boldsymbol{D}, \boldsymbol{G}, \boldsymbol{H})$ using GraphPad Prism software. Mean \pm SE. ${ }^{* *} p<0.01,{ }^{* * *} p<0.0001$. Scale bars: $\boldsymbol{A}, 100 \mu \mathrm{m} ; \boldsymbol{C}, \boldsymbol{E}, 50 \mu \mathrm{m} ; \boldsymbol{F}, 20 \mu \mathrm{m}$.

rabbit anti-phospho-4E-BP1 (Ser65) (1:500, \#9451; Cell Signaling Technology), rabbit anti-total 4E-BP1 (1:500, \#9644; Cell Signaling Technology), rabbit anti-4E-BP2 (1:500, \#2845; Cell Signaling Technology) rabbit anti-Cyclin D1 (1:700, mAb \#2978 Cell Signaling), mouse anticyclin D3 (1:700, mAb \#2936; Cell Signaling Technology), rabbit anticyclin-dependent kinase 2 (1:700, CDK2, mAb \#2546; Cell Signaling
Technology), rabbit anti-cyclin-dependent kinase 4 (1:700, CDK4, mAb \#12790; Cell Signaling Technology), and rabbit anti-p27 Kip1 (1:500, $\mathrm{mAb}$ \#3686; Cell Signaling Technology). Near-infrared fluorescent secondary antibodies (LI-COR) were used at 1:10,000. Proteins were visualized on an Odyssey Infrared Imaging System (LI-COR). Protein levels were normalized to respective controls (i.e., GAPDH or $\beta$-actin). Quan- 
tification was done using Image Studio version 5.2 software (LI-COR) and are presented as mean \pm SEM.

Electron microscopy. Mice $(n=13 ; 7$ males, including $4 \mathrm{KO}$ and 3 controls, and $6 \mathrm{fe}-$ males, including $3 \mathrm{KO}$ and 3 controls) were perfused with modified Karnovsky's fixative ( $2 \%$ paraformaldehyde/2\% glutaraldehyde) in Sorenson buffer, pH 7.4, followed by overnight postfixation of the brains in the same solution. Tissue was then dissected using a stereomicroscope, postfixed again with $1 \%$ osmium tetroxide, dehydrated in ascending grades of acetone, and embedded in resin (Embed 812; Electron Microscopy Sciences) using a PELCO Biowave Pro tissue processor (Ted Pella). Semi-thin sections $(1-5 \mu \mathrm{m})$ were cut and stained with toluidine blue; ultrathin sections $(80-100 \mathrm{~nm})$ were mounted on copper grids and stained with uranyl acetate and lead citrate and viewed with a transmission electron microscope (Tecnai G2; FEI).

Cell counting and analysis. Sections from similar regions of brain and spinal cord were imaged using Leica SP5; Olympus FV1000, and Zeiss LSM780 (equipped with two photon) confocal microscopes at magnification $10 \times$ (numerical aperture, $\mathrm{NA}=0.4), 60 \times$ water $(\mathrm{NA}=1.4)$ $100 \times$ oil-immersion $(\mathrm{NA}=1.46)$, respectively. Cells were counted by semiautomated methods using ImageJ and Fiji plugins and macros (selfwritten and optimized for different immunostainings) after adjustment for contrast, grid, and threshold values. Maximum projections of stacks and multichannel on/off macros were also used wherever necessary for better visualization.

Statistical analysis. Numerical values were analyzed using mean \pm SEM and are presented as bar graphs. Group means were compared using Student's $t$ test (unpaired) and two-way ANOVA followed by post hoc Tukey's/Bonferroni's/Sidak's multiple-comparisons tests where necessary using GraphPad Prism. Significance is denoted as ${ }^{\star} p<0.05,{ }^{* *} p<$ $0.01,{ }^{* *} p<0.001$, and ${ }^{* * *} p<0.0001$ in the figures.

\section{Results}

\section{Generation and validation of Olig1-Cre specific ILK} cKO mice

Olig1-Cre ${ }^{+/-} \times I L K^{\mathrm{fl} /+}$ mice crossed with $I L K^{\mathrm{fl} / \mathrm{fl}}$ mice (Fig. $1 A$ ) had small litter sizes, with few mutant (ILK cKO) pups $(\sim 3 \%$ mutant pups vs the expected 25\%) and a high death rate for the ILK cKO animals. Only a few animals survived to postnatal day 30 (P30) and the maximum survival was 3 months. Therefore, deletion of ILK in Olig1-expressing cells had a dramatic negative effect on overall viability.

To validate ILK deletion in the cKO mutant line, we immunostained coronal brain sections at P10 and found that ILK protein was reduced in the corpus callosum (Fig. $1 B$ ). In control mice, ILK was expressed in mature CC1-positive oligodendrocytes (arrows) and to a lesser extent by NG2-positive oligodendrocyte progenitor cells (OPCs, arrowheads at OPC processes; Fig. 1C). In mature cells, ILK was expressed in the cell body and processes in control mice, but was absent in ILK cKO cells (Fig. $1 C)$. Western blot analysis demonstrated that ILK expression was already reduced at $\mathrm{P} 0$ in the $\mathrm{cKO}$ mice (Fig. $1 D$ ). cKO mutant pups were significantly smaller in body size/weight through development (Fig. 1E); the brains were smaller and spinal cords appeared thinner, as can be seen at P21 in Figure 1D. Clearly, deletion of ILK in Olig1-expressing cells had a long-term impact on both brain and whole animal development (Fig. 1E).
ILK deletion resulted in a dramatic decrease in oligodendrocyte lineage cells and myelination in brain The number of Olig2-positive cells was quantified in rostral corpus callosum (boxes in corpus callosum in Fig. 2A) from P0 to $\mathrm{P} 30$ and was found to be significantly reduced in ILK cKO pups compared with control ${ }^{\mathrm{fl} / \mathrm{fl}}$ pups through development (Fig. $2 B, C)$. ILK deletion also appeared to reduce Olig2 intensity in cells at P10 (Fig. 2B). Cells expressing NG2, Olig2, Sox2, or Hoechst (Fig. 2D) were quantified in P0 midline corpus callosum and a significant decrease in the number of Sox $2+$ cells, Olig2+, and NG2+ cells (Fig. 2E) was noted. The percentage of Sox2+ cells expressing Olig2 or NG2 was also quantified (Fig. 2F) and they were all significantly downregulated in ILK cKO pups. Therefore, at birth, there were fewer Sox $2+$ progenitor cells and fewer of these cells had differentiated to the oligodendrocyte lineage. At P10, proliferating Ki67+ cells were quantified (Fig. $2 G, H)$ and a significant decrease in Ki67-positive cells was seen in corpus callosum, with much of this reduction occurring in Sox10-positive cells (Fig. $2 H$ ).

We further identified mature oligodendrocytes at $\mathrm{P} 10$ by $\mathrm{CC} 1$ immunostaining (Fig. 3A). The number of total Olig2-positive cells was reduced in $\mathrm{cKO}$ mice, with a dramatic loss of mature oligodendrocytes (Fig. 3B). Colabeling for Olig2 and CC1 (Fig. $3 C$ ) indicated that the percentage of Olig2 cells that were CC1+ was particularly low $(<5 \%)$ in ILK cKO pups compared with close to $20 \%$ in control animals (Fig. 3D).

To further characterize these mice, we crossed our PLP-EGFP transgene (Mallon et al., 2002) into the control and cKO lines to generate ILK $\mathrm{cKO} \times \mathrm{PLP}-\mathrm{EGFP}^{+/-}$mice and control $\mathrm{ILK}^{\mathrm{fl} / \mathrm{fl}} \times$ PLP-EGFP $^{+/-}$mice. EGFP cKO mice not only had fewer PLPEGFP cells, but also a prominent decrease in PLP-EGFP fluorescence within myelinated segments (Fig. $3 E$ ). It should be noted that, as would be expected, ILK deletion also reduced the number of Sox10-positive cells in cKO corpus callosum (cf. red Sox10 images; Fig. 3E). When sections were stained for myelin basic protein (MBP; red), and neurofilament (NF, blue; Fig. $3 F$ ), MBP immunostaining was reduced significantly (Fig. $3 G$ ), whereas $\mathrm{NF}$ immunofluorescence remained unchanged (Fig. $3 H$ ). Concurrently, whereas the total number of Hoechst-positive cells per view was unchanged, GFAP immunostaining increased in the same region of $\mathrm{P} 10$ corpus callosum, suggesting astrocytic hypertrophy (Fig. 4). However, the corpus callosum and other white matter tracts were thinner in ILK cKO mice. Because Olig1 is expressed quite early during embryonic development, it was possible that a subpopulation of neurons was affected directly by ILK deletion. We therefore quantified NeuN-positive neurons in cortical gray matter regions (Fig. 5A,B) in control PLP-EGFP and 
A

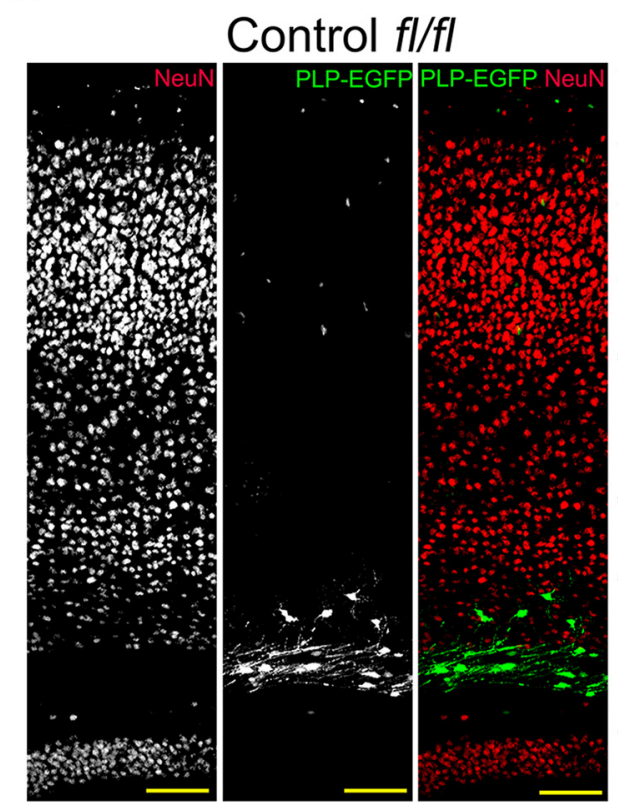

B

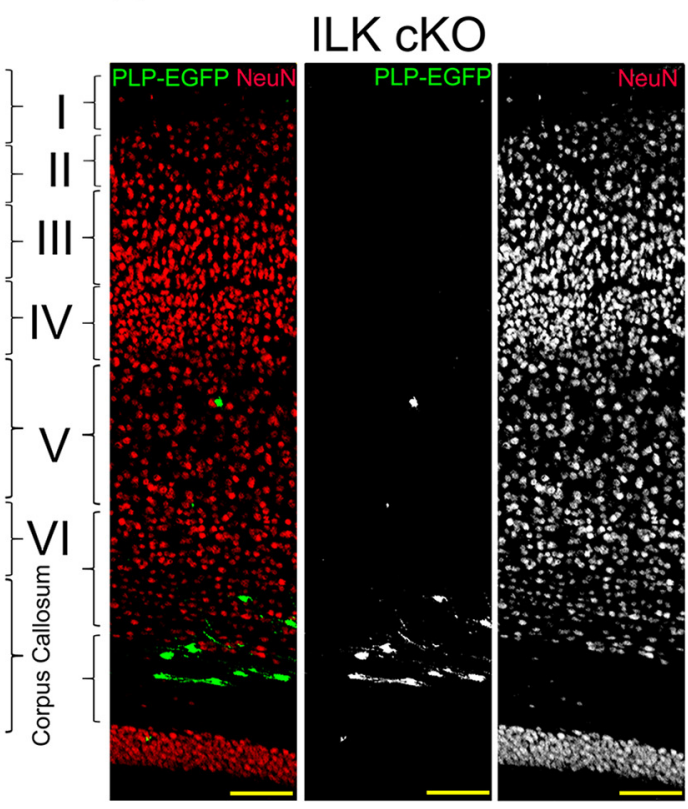

C

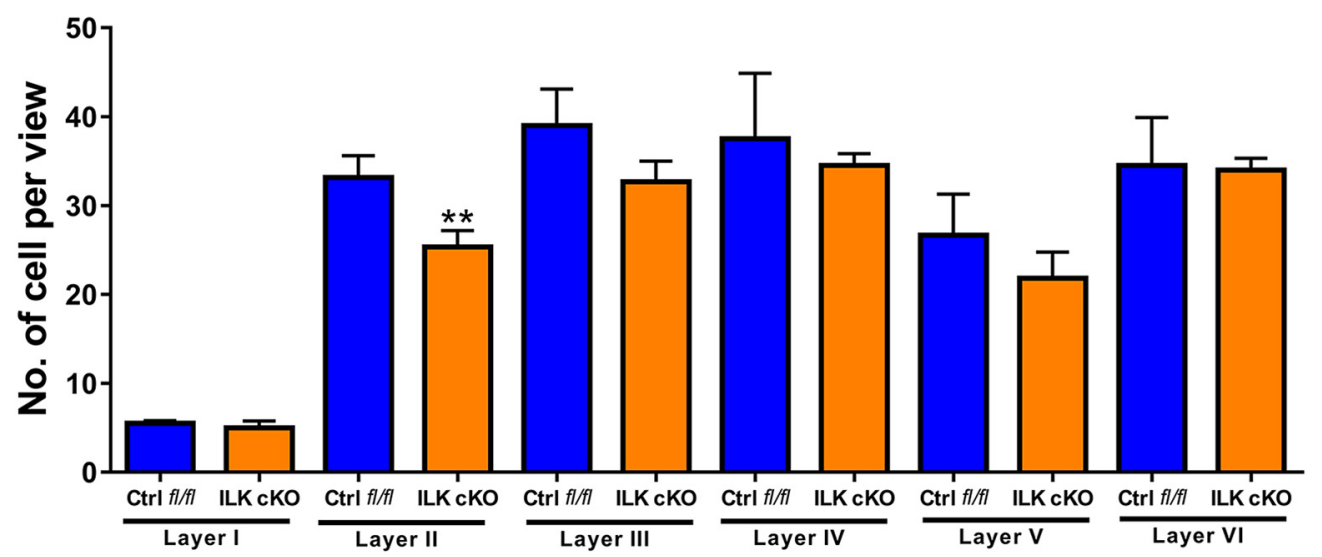

Figure 5. ILK deletion does not affect the total number of cortical neurons (NeuN +) in ILK cKO pups at P10. Slices taken from control $(\boldsymbol{A})$ and ILK cKO $\times$ EGFP $(\boldsymbol{B})$ mice at P10 were immunostained for NeuN (red, $\boldsymbol{A}, \boldsymbol{B})$. Quantification in six different layers of cerebral cortex indicates no significant difference $(p>0.05)$ except layer II (** $p<0.01)$. Data were analyzed by two-way ANOVA using GraphPad Prism software. Scale bar, $50 \mu \mathrm{m}$.

ILK $c K O \times$ PLP-EGFP pups. No significant change in the number of neurons was noted between control and cKO pups except in layer II (Fig. 5C).

\section{Severe impact of ILK deletion on OPC proliferation in} oligodendrocyte-enriched cultures

We further confirmed our findings that ILK inhibition/deletion reduced the pool of OPCs in in vitro systems. Oligodendrocyteenriched cultures were prepared (Fig. 6A) from P0 rat pups or from transgenic mouse pups (control PLP-EGFP and ILK cKO $\times$ PLP-EGFP; 95\% OPCs). Rat cells were treated with the ILK inhibitor cpd 22 (ILK-I) and all doses (100 nM-10 $\mu \mathrm{M})$ reduced the number of OPCs significantly (data not shown). Most importantly, proliferating OPCs expressing Ki67 were significantly downregulated $(82.06 \pm 3.59$ vs $57.56 \pm 5.91$ in control vehicle and ILK-I treated cultures, respectively). The loss of ILK also had a striking effect in cultures prepared from transgenic pups. ILK cKO OPCs not only were fewer in number, but also appeared less differentiated, as can be seen by PLP-EGFP (green) and NG2 (cyan) expression (Fig. 6B). There was an overall decrease in the total number of proliferating Ki-67-positive cells and the percentage of PLP-EGFP and NG2 cells that were proliferating was also reduced (Fig. 6C). It should be noted that, in contrast to in vivo, PLP-EGFP cells proliferate in primary culture because the promoter is expressed at earlier stages.

OPC deficit in spinal cord and overall impact on ultrastructure of myelin

As in the brain, in ILK cKO spinal cord, there were reduced numbers of PLP-EGFP cells (Fig. 7A,D), NG2-positive OPCs (Fig. $7 B, E$ ), and mature oligodendrocytes (Fig. $7 B, D, F)$ and reduced myelin expression (Fig. $7 \mathrm{~A}, C$ ) in the dorsal column white matter and central gray matter regions.

Given the reduction in myelin protein, we investigated myelin structure in corpus callosum and spinal cord white matter tracts from P30 control and cKO mice by electron microscopy. Repre- 
A

\begin{tabular}{|c|c||c|} 
Mouse mix glia culture & & \multicolumn{2}{|c|}{$\begin{array}{c}\text { Oligodendiferation Media } \\
\text { P0 }\end{array}$} & $\begin{array}{c}\text { S days } \\
\text { Shaking/detachment }\end{array}$ & 3 days & DIV 13
\end{tabular}

B

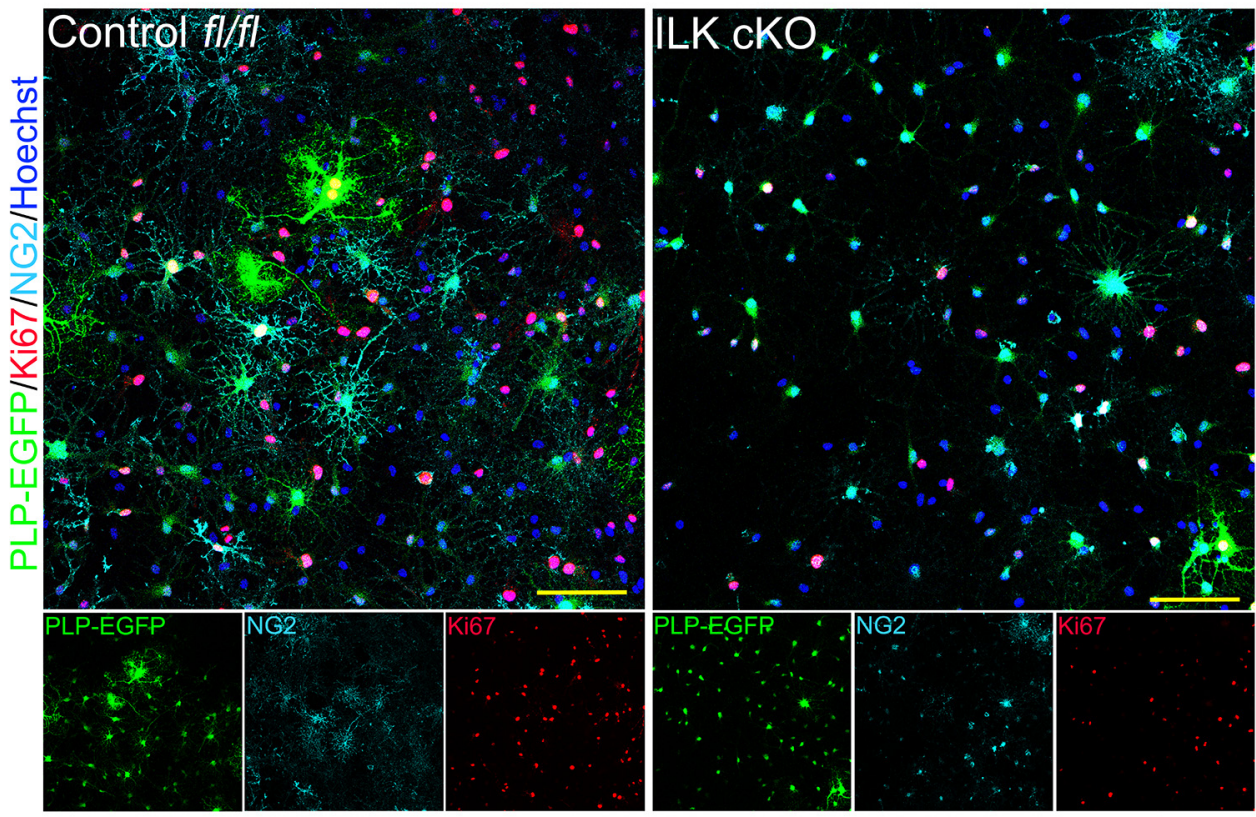

C

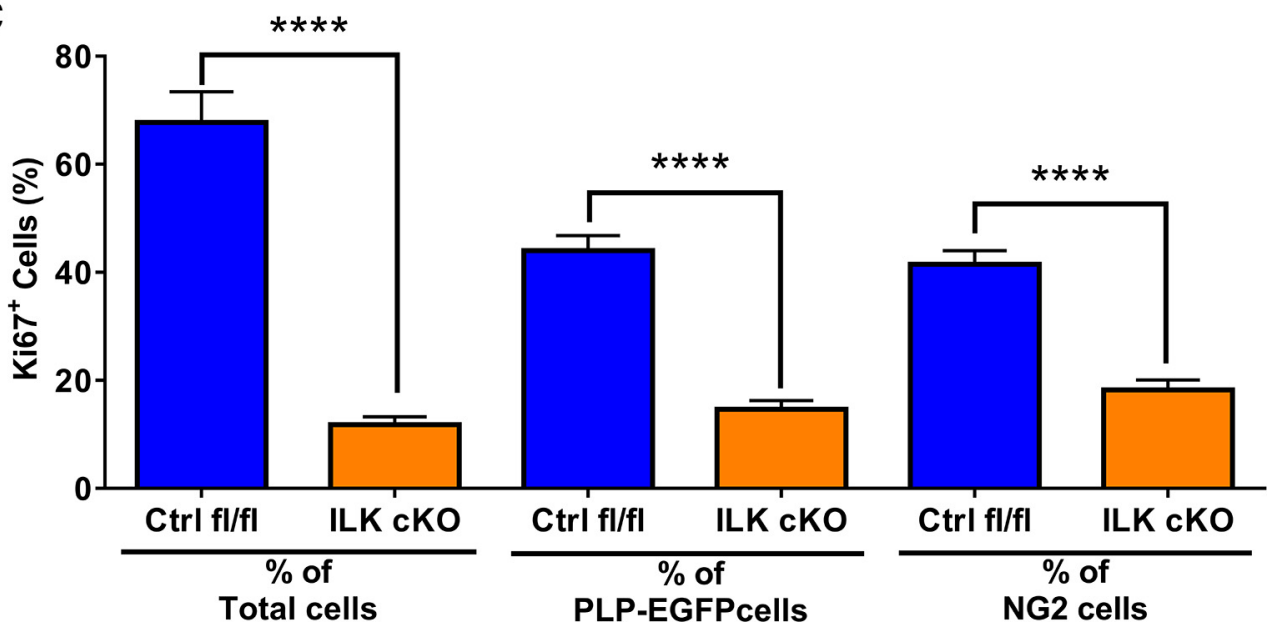

Figure 6. Proliferation of mouse OPCs was severely impaired in the absence of ILK in oligodendrocyte-enriched cultures. Mixed glia cultures were prepared from control PLP-EGFP ( $n=3$ ) and ILK CKO $\times$ PLP-EGFP $(n=4)$ mouse pups. Cells were further purified and replated to obtain oligodendrocyte-enriched cultures (Scheme, $\boldsymbol{A})$. OPCs were immunostained for Ki67 (red), NG2 (cyan), and Hoechest (blue; $\boldsymbol{B}$ ). Quantification indicates a significant decrease in the total number of proliferating cells and of proliferating PLP-EGFP and NG2 cells in particular ( $\boldsymbol{C}$ ). Data were analyzed by two-way ANOVA followed by post hoc Tukey's test, ${ }^{* * * *} p<0.0001$. Error bars: Mean \pm SE. Scale bar, $100 \mu \mathrm{m}$.

sentative images of corpus callosum (Fig. $8 A$ ) or spinal cord white matter tract (dorsal column; Fig. $8 B$ ) of control or ILK cKO mice are shown. The percentage of myelinated axons in corpus callosum and spinal cord was determined and a significantly lower number of myelinated axons was seen in ILK cKO in both regions relative to control (Fig. $8 C$ ). The distribution of myelinated axons (Fig. 8D) and the myelin g-ratio (Fig. $8 F, G$ ) in the corpus callosum were significantly different in $\mathrm{CKO}$ mice relative to control mice, with small-diameter myelinated axons and thinner myelin being more abundant in the cKO mice. Unexpectedly, in spinal cord, no difference in the axon diameter (Fig. $8 E$ ), the g-ratio (Fig. $8 F$ ), or the trend line slope (Fig. $8 H$ ) was seen between control and cKO samples. Therefore, there were significantly fewer myelinated axons in both the spinal cord and corpus callosum, presumably because there were fewer oligodendrocytes, and, in corpus callosum, this resulted in thinner myelin. However, spinal cord oligodendrocytes could generate myelin of normal thickness with a normal size distribution of myelinated axons despite their loss of ILK.

Effect of ILK deletion on downstream signaling pathways in brain

Our findings that ILK loss in Olig1-expressing cells reduced the number of OPCs, mature oligodendrocytes, and myelination led us to investigate the underlying mechanisms of reduced cell number. Control and ILK cKO cerebrum samples were analyzed by 
A

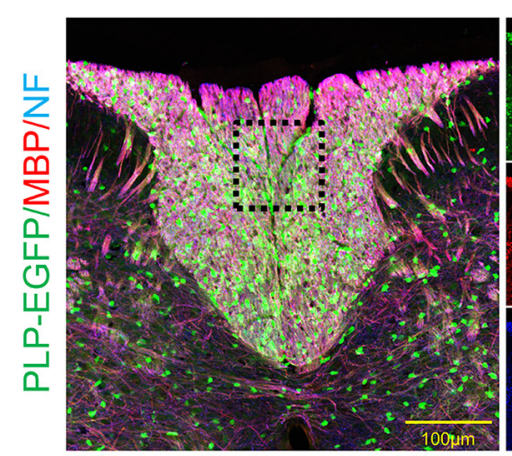

Ctrl fl/fI

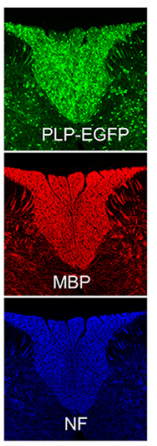

ILK cKO

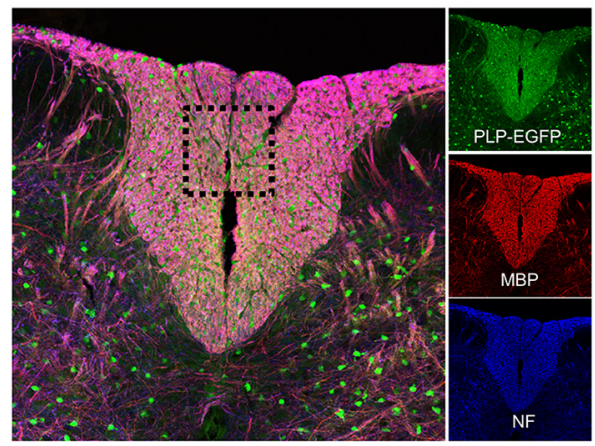

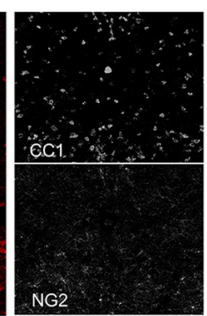

C
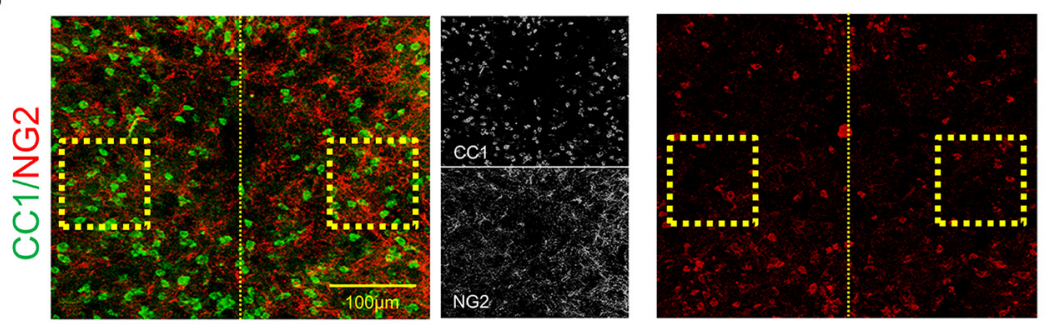

NG2

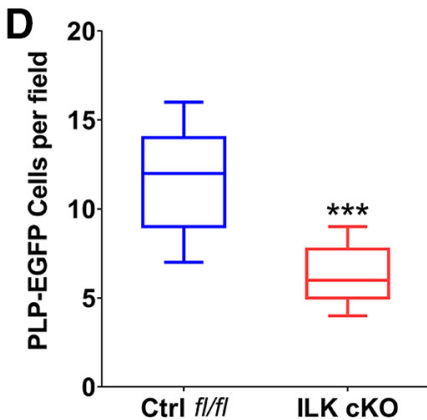

E

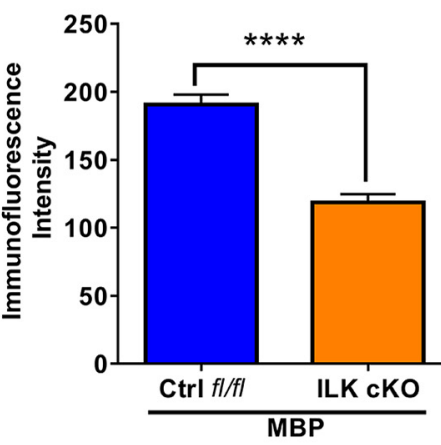

ns
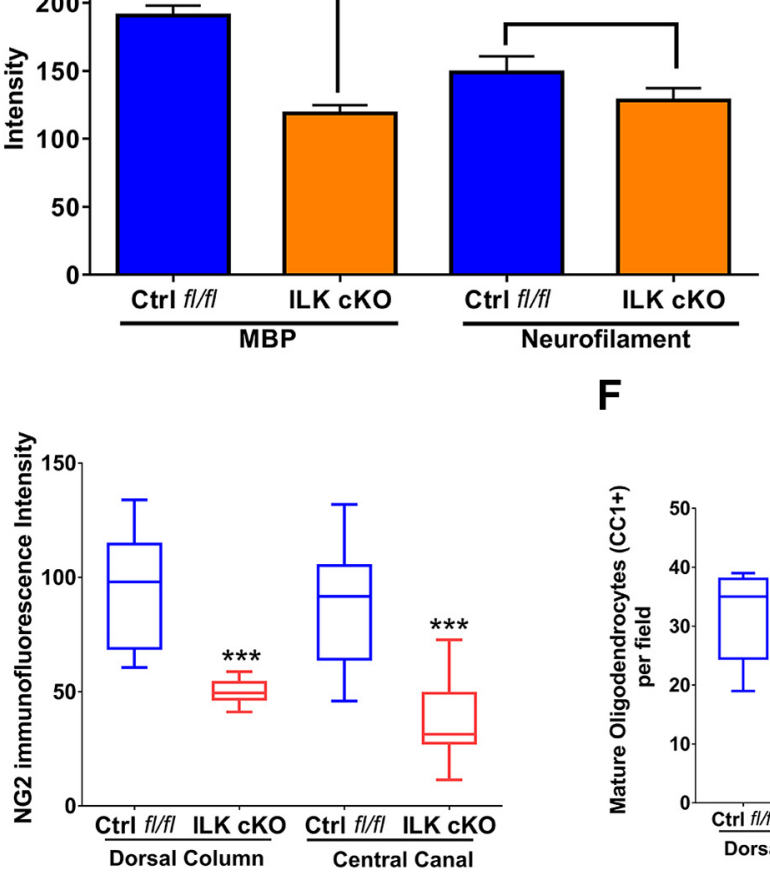

F

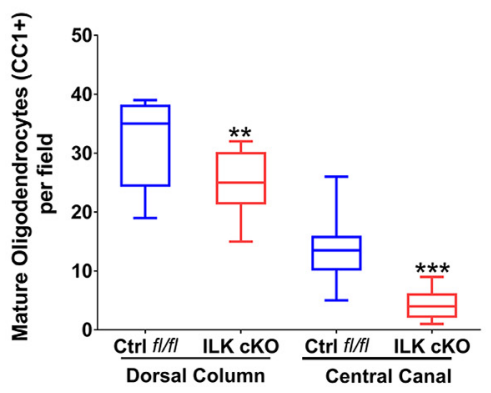

Figure 7. Conditional ablation of ILK results in significant decrease in the number of OPCs and mature oligodendrocytes in spinal cord. Immunostaining for MBP, NF, mature oligodendrocytes $(C C 1)$, and NG2 (OPCS) in P16 spinal cord $(\boldsymbol{A}, \boldsymbol{B})$ and quantification in dorsal columns $(\boldsymbol{C}-\boldsymbol{F})$ and central canal $(\boldsymbol{E}, \boldsymbol{F})$. Data were obtained from 3 animals per group with multiple sections $(>2)$. Data were analyzed using two-way ANOVA followed by Tukey's multiple-comparisons test $(\boldsymbol{C}, \boldsymbol{E}, \boldsymbol{F})$ and unpaired Student's $t$ test $(\boldsymbol{D})$ in GraphPad software. ${ }^{* *} p<0.01,{ }^{* * *} p<0.001,{ }^{* * * *} p<0.0001$. Scale bar, $100 \mu \mathrm{m}$.

Western blot (Fig. 9). ILK was clearly reduced in cKO cerebrum relative to control, up to $40 \%$ (Fig. $9 A, B$ ), with the remaining ILK likely expressed by other cells in the tissue.

A number of putative ILK substrates were analyzed, including GSK3 $\beta$, but little effect of ILK loss was noted for GSK3 $\beta$ signaling (Fig. 9D). The majority of the impact of ILK loss in Olig1-positive cells was in the Akt/mTOR pathway. As expected, phosphorylation of the ILK substrate Akt 473 was downregulated in ILK cKO mice (Fig. 9C,D). ILK deletion also downregulated p-mTOR (Ser 2481 and Rictor; Fig. 9E-G) and p-S6RP (Ser 240/244 and Ser 235/236; Fig. 9H-J). There was also a significant decrease in phosphorylation of translation initiation factor (elF4E)-binding protein 4EBP1 at Ser 37/46 (Fig. 9K,L) and Ser 65 (Fig. 9K, M). To assess oligodendrocyte-specific changes of pAKT Ser 437 and pS6RP Ser 240/244, we immunostained control and ILK cKO mice carrying the PLP-EGFP transgene. Both phospho-Akt Ser 
A

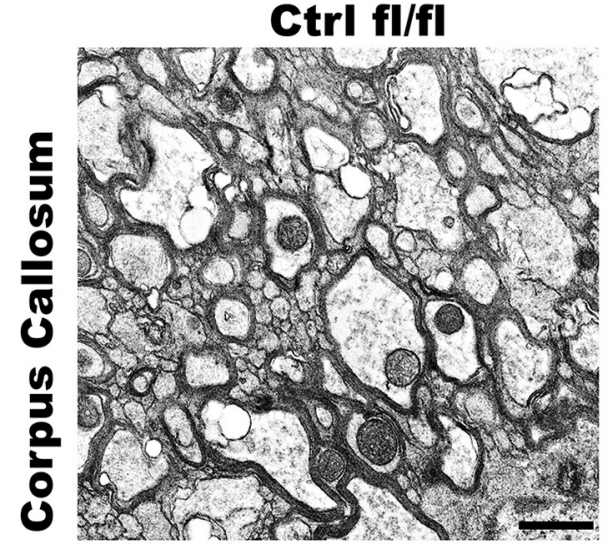

B

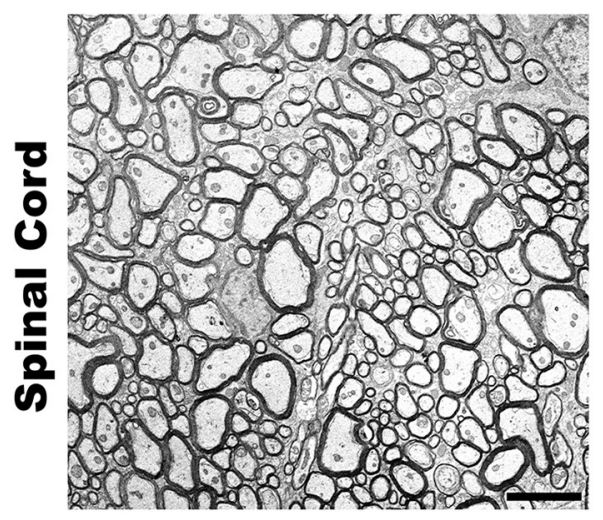

F

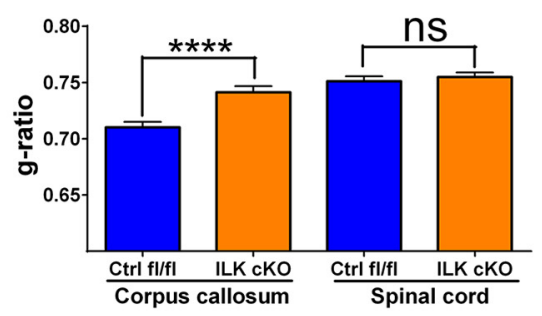

ILK CKO
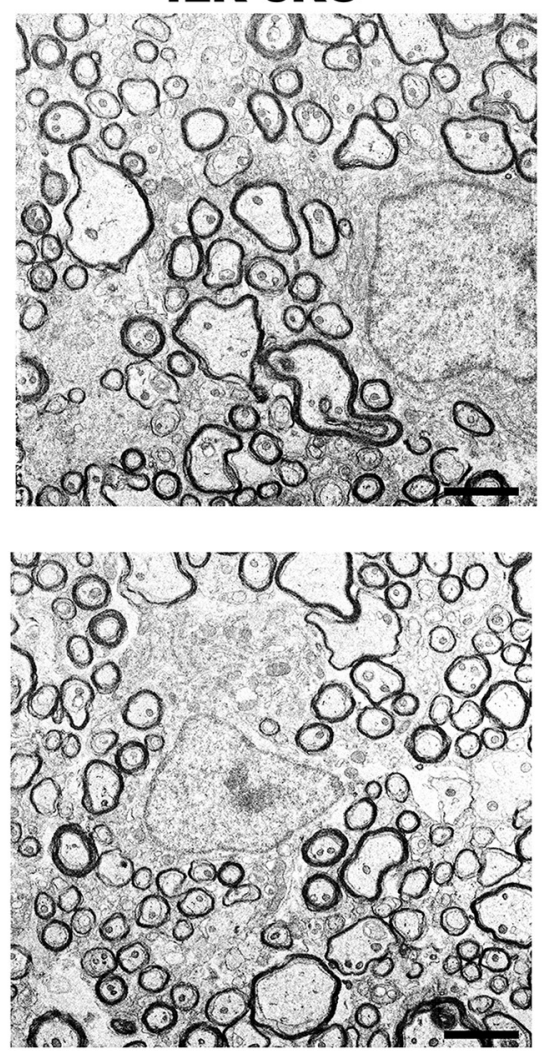

G

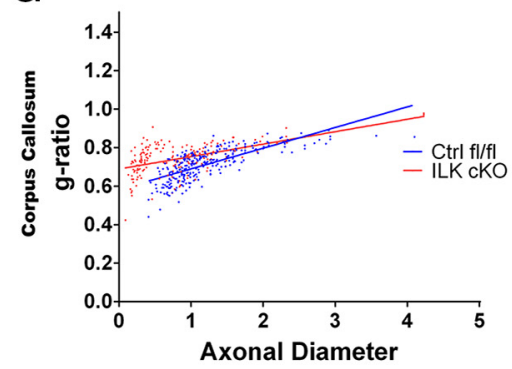

C

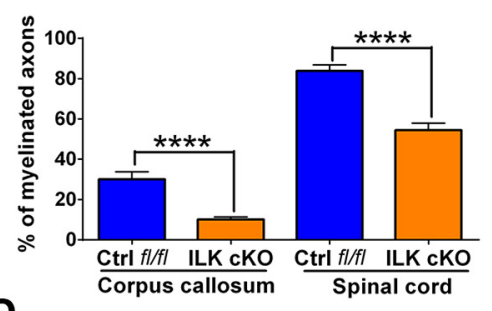

D
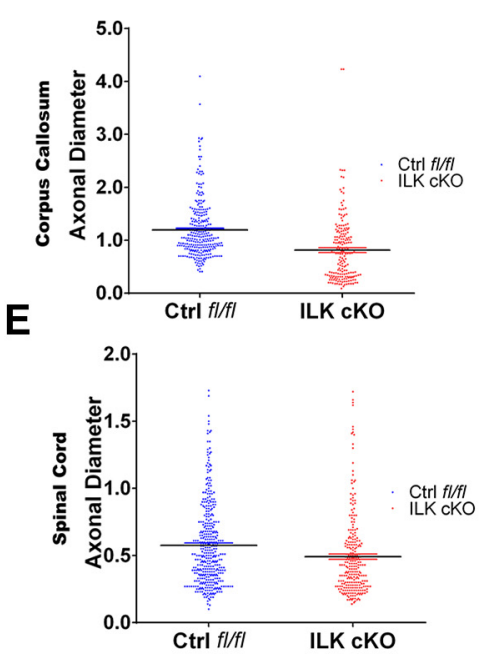

H

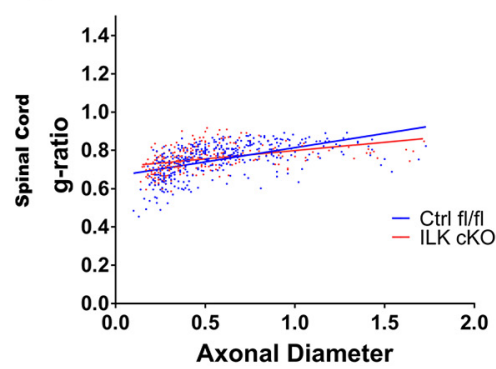

Figure 8. Loss of ILK in myelinating oligodendrocytes impaired myelination in corpus callosum and spinal cord. Shown is an electron micrograph from corpus callosum (A) and spinal cord (dorsal column, $\boldsymbol{B}$ ) of control and ILK cKO mice. The percentage of myelinated axons in corpus callosum and spinal cord was quantified ( $\boldsymbol{C}$. A significantly lower number of myelinated axons was seen in ILK cKO corpus callosum and spinal cord relative to control. The distribution of myelinated axons $(\boldsymbol{D})$ and the myelin g-ratio $(\boldsymbol{F}, \boldsymbol{G})$ in the corpus callosum were significantly different $(* * * * p<$ $0.0001)$ in cKO mice relative to control mice, with small-diameter axons more abundant in the cKO mice $(\boldsymbol{D})$. No difference in axon diameter $(\boldsymbol{E})$, g-ratio $(\boldsymbol{F})$, or slope of trend line $(\boldsymbol{H})$ was seen between control and $c K 0$ spinal cord $(p>0.05)$. Quantification of total axon counts, myelinated axons, and myelin thickness was done in 4 representative sections/animal ( $n=6$ ). Data were subjected to multiple statistical analyses: linear regression analysis ( $F=20.838$ and $F=12.518$ for $\boldsymbol{G}$ and $\boldsymbol{H}$ respectively) and two-way ANOVA followed by Tukey's multiple-comparisons test ( $\boldsymbol{C}$, $\boldsymbol{F})$. Axonal diameter is shown as a scatter plot $(\boldsymbol{D}, \boldsymbol{E})$ using GraphPad Prism software. ${ }^{* * * *} p<0.001$. Scale bars, $2 \mu \mathrm{m}$.

473 (pAKT473; Fig. 10A) and phospho-S6RP (Fig. 10B) were downregulated in Sox10/PLP-EGFP-positive oligodendrocyte lineage cells in ILK cKO mice.

Deletion of ILK altered expression of cell cycle proteins in oligodendrocytes

ILK deletion in oligodendrocytes reduced phosphorylated AKT473 significantly (Fig. 9). We noted a reduced number of oligodendrocytes in the cKO animals (Fig. 2) and studies in other cells suggested that one role of ILK may be to affect the cell cycle (Grashoff et al., 2003; Smeeton et al., 2010). We therefore investigated the cell cycle in oligodendrocytes in these mice. To evaluate the direct impact of ILK deletion and the subsequent reduction in phosphorylation of AKT and S6RP, we performed Western blot for the major proteins involved in cell cycle regulation. Therefore, control and ILK cKO cerebrum were analyzed for cell cycle protein expression. Cyclin D1, cyclin D3, cdk2, and cdk4 were all downregulated in the tissue (Fig. 11A-E). When control and cKO samples carrying the PLP-EGFP transgene were investigated by immunofluorescence, expression of all of these proteins was downregulated in the nuclei of Sox10/PLP-EGFP-positive cells (Fig. 11F-I).

Finally, we analyzed the expression of p27kip, a negative regulator of cyclin and cyclin-dependent kinase proteins, which was dramatically upregulated in the tissue (Fig. 12A,B). Immunostaining samples from control and ILK cKO mice carrying the PLP-EGFP transgene demonstrated that $\mathrm{p} 27 \mathrm{kip} 1$ expression was clearly upregulated in the nucleus of Sox10/PLP-EGFP-positive cells (Fig. 12C,D). 


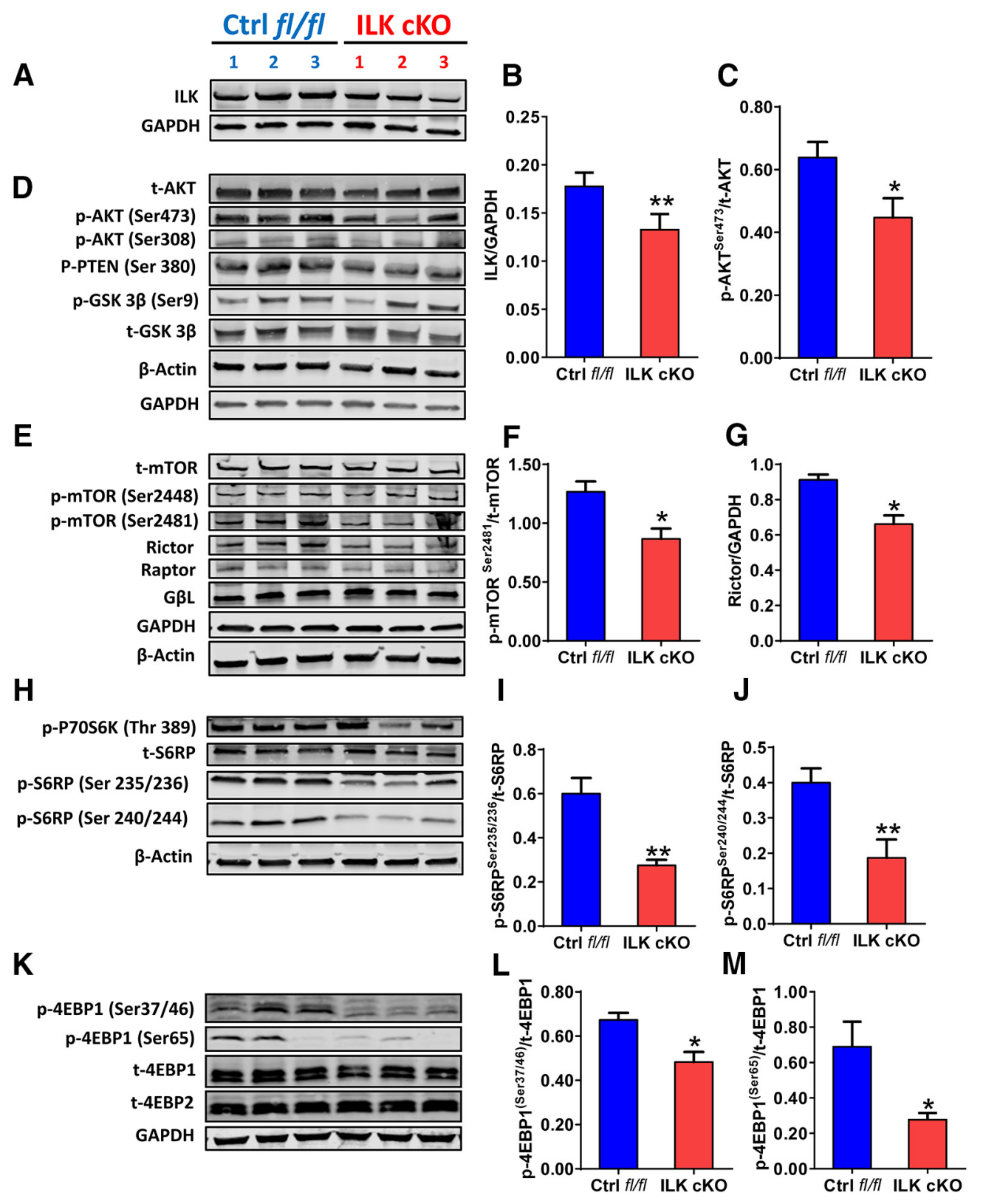

Figure 9. Effect of ILK deletion on downstream signaling pathways in the brain. Control and cKO cerebrum samples were analyzed by Western blot (A). ILK was clearly reduced in cKO cerebrum relative to control $(\boldsymbol{A}, \boldsymbol{B})$. Akt, PTEN, GSK3 $\beta$, and mTOR signaling were quantified. Only molecules showing statistically significant changes are presented in graphs $(\boldsymbol{B}, \boldsymbol{C}, \boldsymbol{F}, \boldsymbol{G}, \boldsymbol{I}, \boldsymbol{J}$, and $\boldsymbol{L}, \boldsymbol{M})$. ILK deletion downregulated p-AKT (Ser473; C, D), p-mTOR (Ser 2481), and Rictor (E-G), p-S6RP (Ser 240/244 and Ser 235/236; $\boldsymbol{H}-\boldsymbol{J}$ ). There was also a significant decrease in phosphorylation of translation initiation factor (elF4E)-binding protein 4EBP1 at Ser37/46 $(K, \boldsymbol{L})$ and Ser65 $(\boldsymbol{K}, \boldsymbol{M})$. Data were subjected to mean \pm SE; group means were compared by unpaired Student's $t$ test using GraphPad Prism software. $n=3$ /group. ${ }^{*} p<0.05,{ }^{* *} p<0.01$.

\section{Discussion}

The current studies focused on the hypothesis that ILK, which is localized at the plasma membrane, might serve as a bridge between extrinsic and intrinsic factors regulating oligodendrocyte development. More than a dozen ILK-binding proteins have been identified (McDonald et al., 2008b). Of particular importance are the proteins that regulate the cytoskeleton organization by linking F-actin to the integrin cytoplasmic tail (Wu and Dedhar, 2001). In addition, integrin signals can be mediated through ILK, which functions as a molecular scaffold at cell-extracellular matrix adhesion sites and participates in signal transduction pathways that control cell survival, differentiation, morphology, proliferation, and gene expression in mammalian cells (Chun et al., 2003). Within focal adhesion (FA) complexes, ILK interacts with other FA proteins such as paxillin, affixin, and parvin (Tu et al., 2001). We had therefore anticipated that ILK would function in regulating the oligodendrocyte cytoskeleton.

ILK mediates actin cytoskeleton in oligodendrocytes in vitro, but its loss does not prevent myelination in vivo

In vitro studies demonstrate that ILK mediates actin cytoskeleton organization and process extension in cultured oligodendrocytes (Chun et al., 2003; O'Meara et al., 2013; Michalski et al., 2016), where it functions as a bridge between the actin cytoskeleton and cell membrane (Chun et al., 2003). Laminin-2 (LN2) is expressed by axons during development and Chun et al. (2003) demonstrated that LN2 induces oligodendrocyte cell spreading through phosphoinositide 3-kinase (PI3K) activation and ILK. Expres- 
A
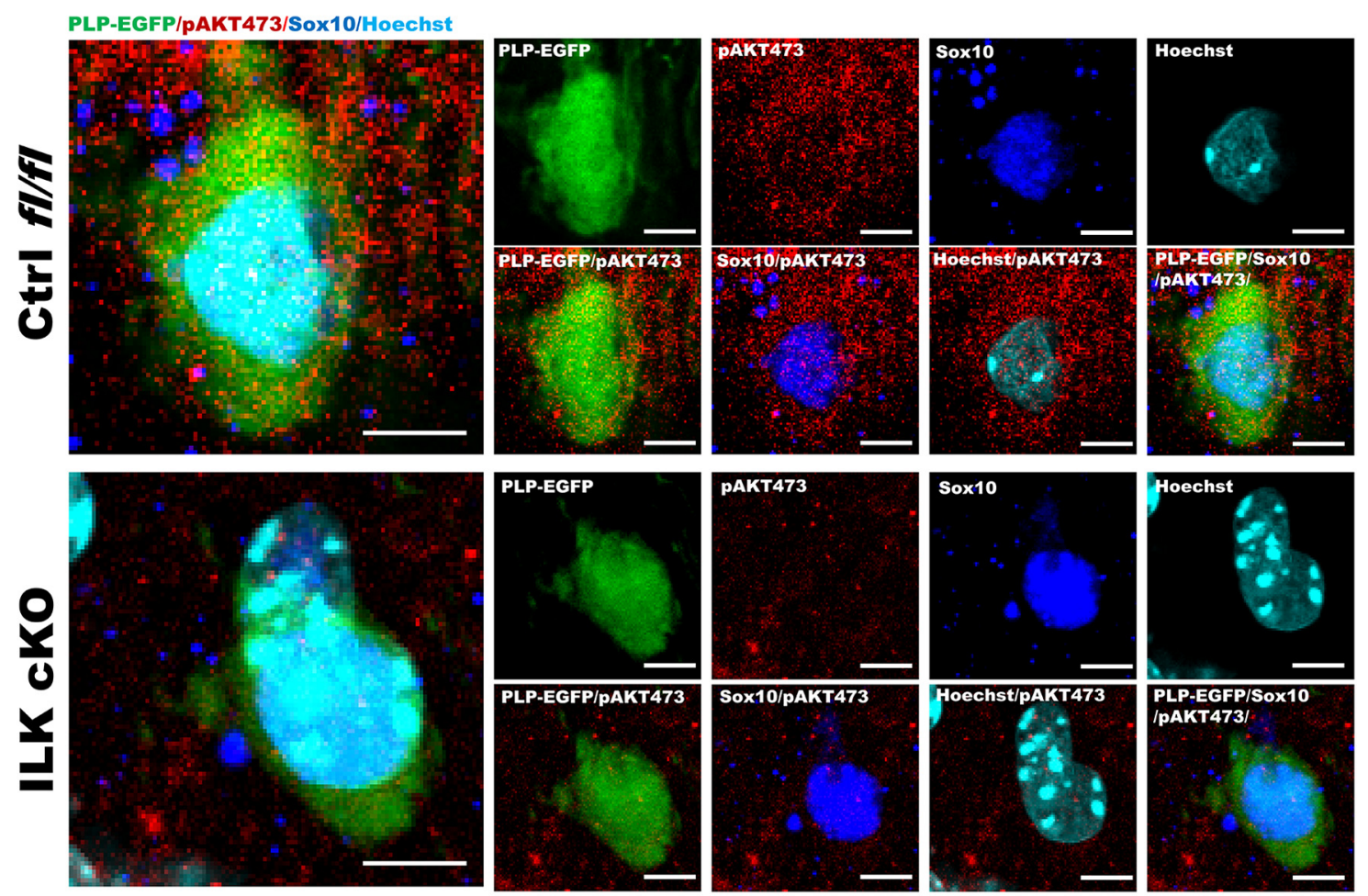

B

CtrI fI/fI
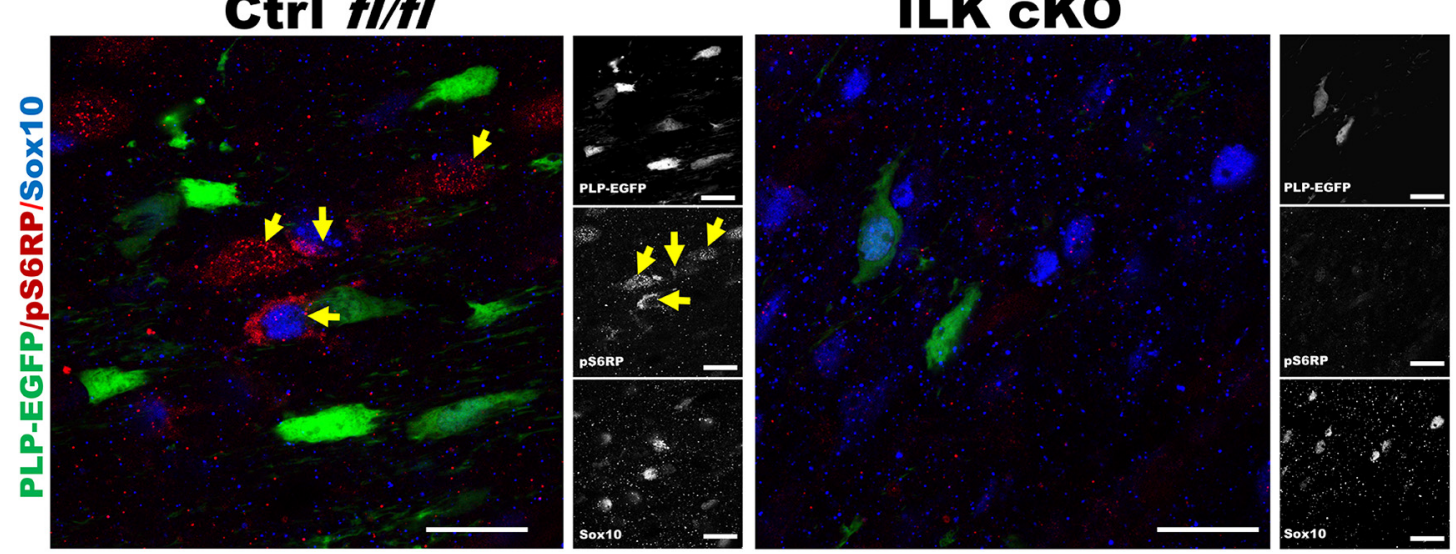

Figure 10. Deletion of ILK downregulated Akt phosphorylation at Akt Ser473 in oligodendrocytes. Control and cKO mice carrying the PLP-EGFP transgene were immunostained for phospho Akt Ser473 and phospho S6 ribosomal protein. Both phospho Akt Ser473 (pAKT473; $\boldsymbol{A}$, red) and phospho S6RP (B, red) were downregulated in Sox10 (blue)/PLP-EGFP-positive oligodendrocyte lineage cells in cKO mice. Scale bars: $A, 5 \mu \mathrm{m} ; \boldsymbol{B}, 20 \mu \mathrm{m}$.

sion of dominant-negative ILK blocks myelin membrane formation that is normally induced by LN2 in culture. Other studies also show that ILK-deficient primary oligodendrocytes fail to extend normal cellular processes and are unable to form myelin membranes upon axonal contact (O’Meara et al., 2013). However, the role of ILK in process extension seems independent of phosphorylation of the canonical downstream targets Akt and GSK $3 \beta$, which remains unaffected after ILK loss. It was thus proposed that the defects are due in part to actin cytoskeleton dysregulation with a corresponding increase in active RhoA levels because the altered cytoskeleton can be restored by pharmacological inhibition of Rho kinase. Interestingly, whereas ILK-deficient oligodendrocytes are severely affected in vitro, they are far less affected when ILK is conditionally deleted in vivo (O'Meara et al., 2013).
Michalski et al. (2016) investigated the mechanism by which ILK loss in murine oligodendrocytes results in severe defects in process branching and outgrowth when cultured on LN-2 substrate, but not on the non-integrin-activating substrate poly-Llysine. They demonstrated that microtubule organization is severely perturbed after ILK loss, with centripetal microtubule looping and failure to bundle occurring in a LN2-independent manner, resulting in decreased process length and myelin production capacity (Michalski et al., 2016).

Our in vitro studies on both rat OPCs treated with an ILK inhibitor and mouse control and cKO cells (Fig. 6) suggest a clear impact on process generation in the absence of ILK. This is consistent with these different in vitro studies demonstrating an impact on the cytoskeleton, although our studies further focus on the impact on cell proliferation. 
A

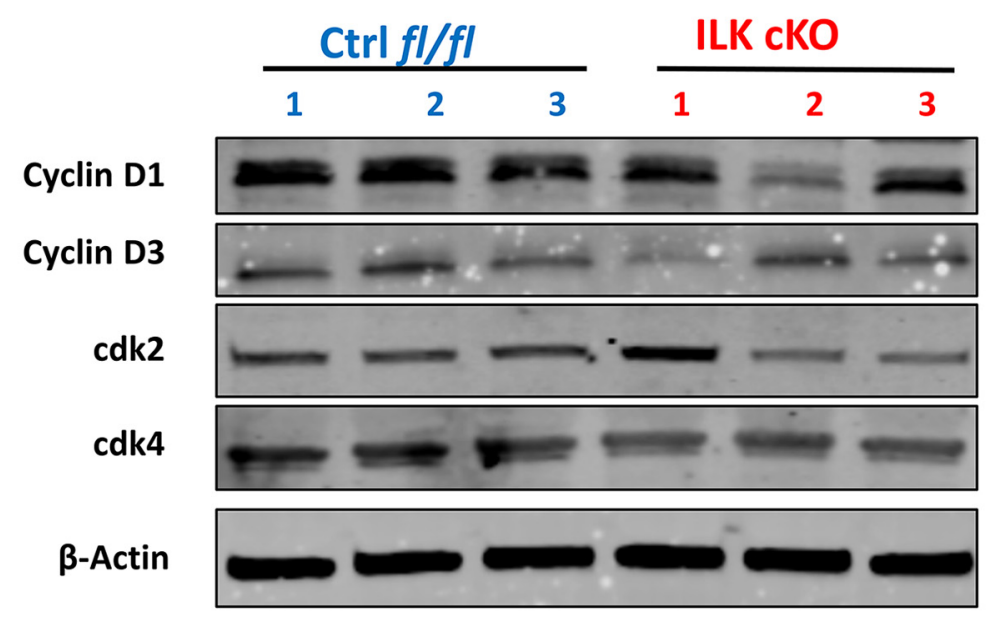

$\mathbf{F}$

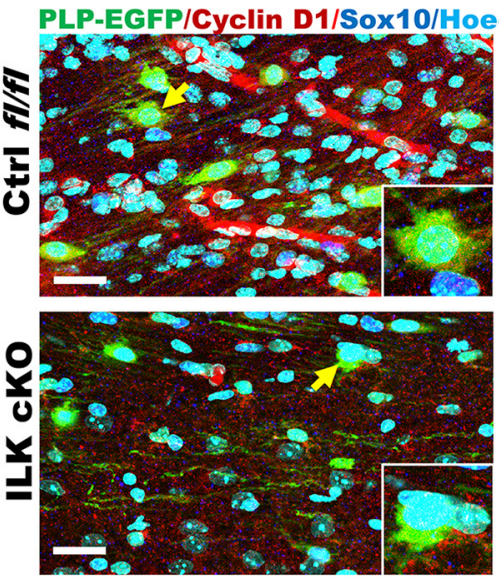

H
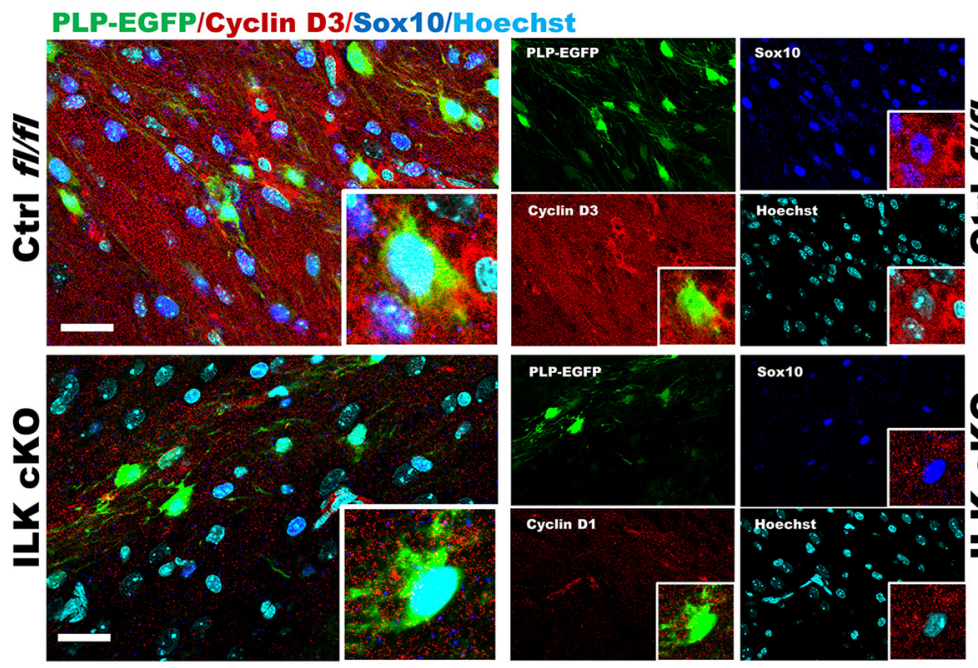

B
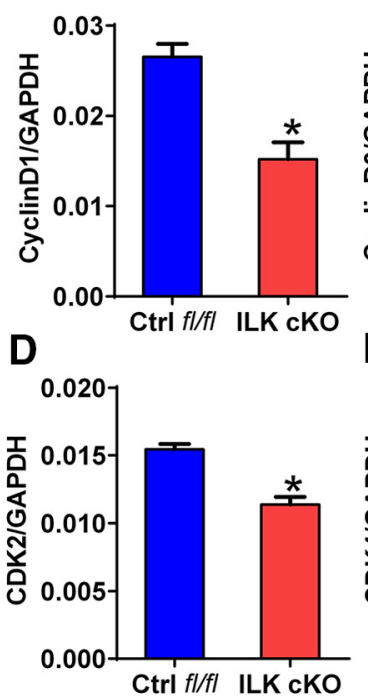

C
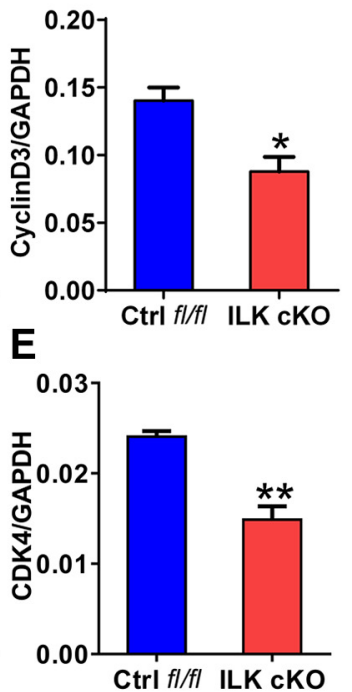

G

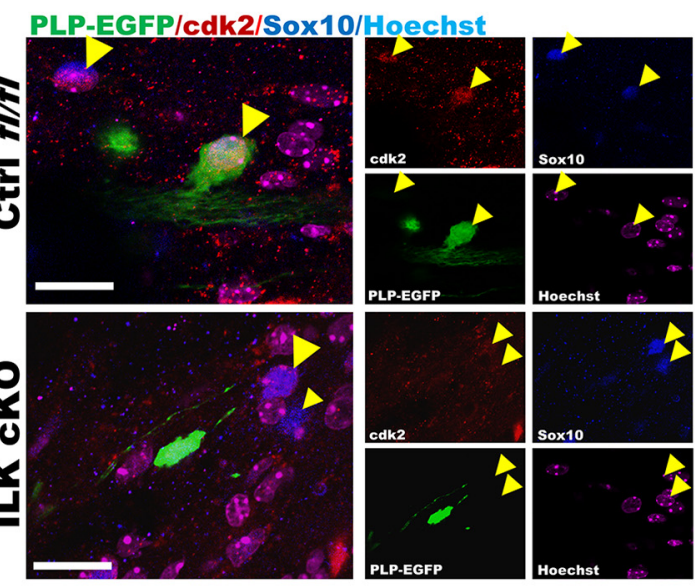

I

PLP-EGFP/cdk4/Sox10/Hoechst
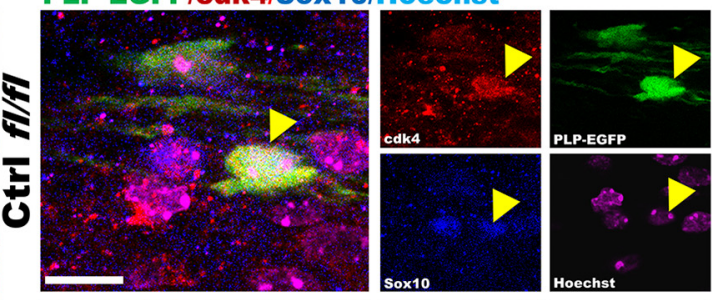

Figure 11. Deletion of ILK downregulated cell cycle proteins in oligodendrocytes. Control and cKO cerebrum was analyzed for cell cycle protein expression: cyclin D1 (A, B), cyclin D3 $(A, C), c d k 2(A, D)$, and $c d k 4(A, E)$, which were all downregulated in the tissue (unpaired $t$-test). When control and cK0 samples carrying the PLP-EGFP transgene were investigated by immunofluorescence, expression of these proteins (red) was downregulated in nuclei of Sox10 (blue)/PLP-EGFP-positive cells $(\boldsymbol{F}-\boldsymbol{I}) . N=6 \mathrm{mice}$. Scale bar, $20 \mu \mathrm{m}$. 
A

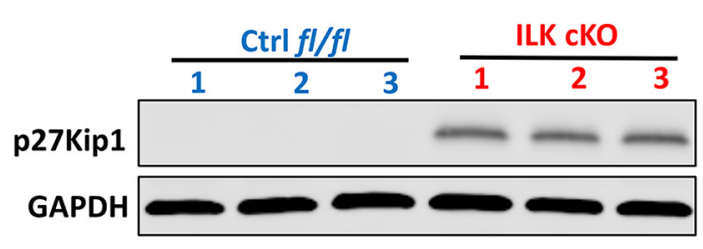

C

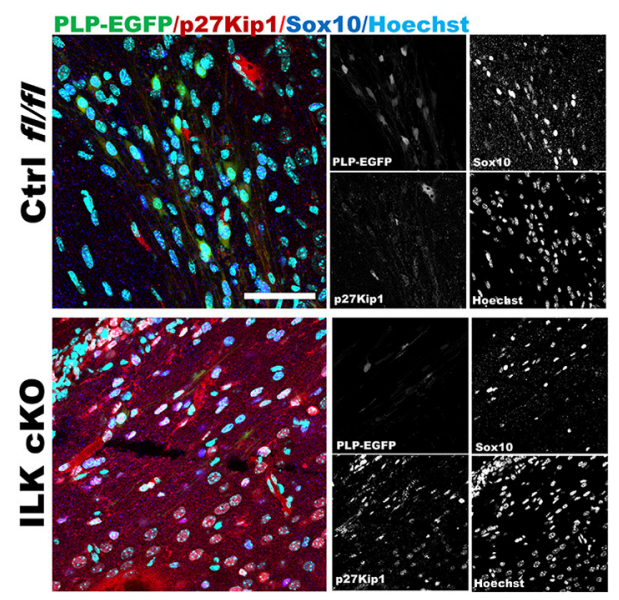

B

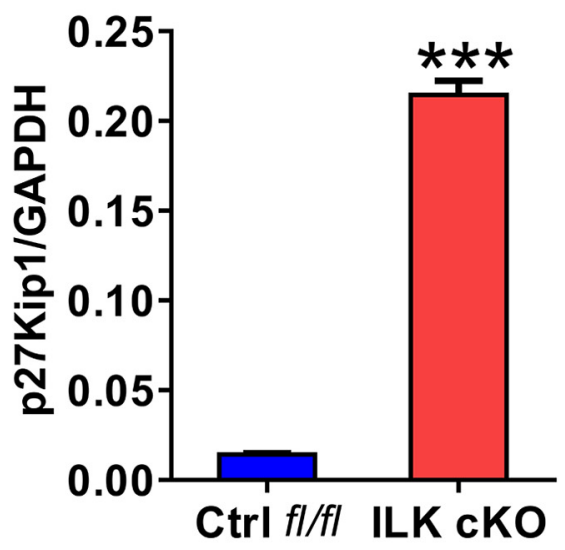

D

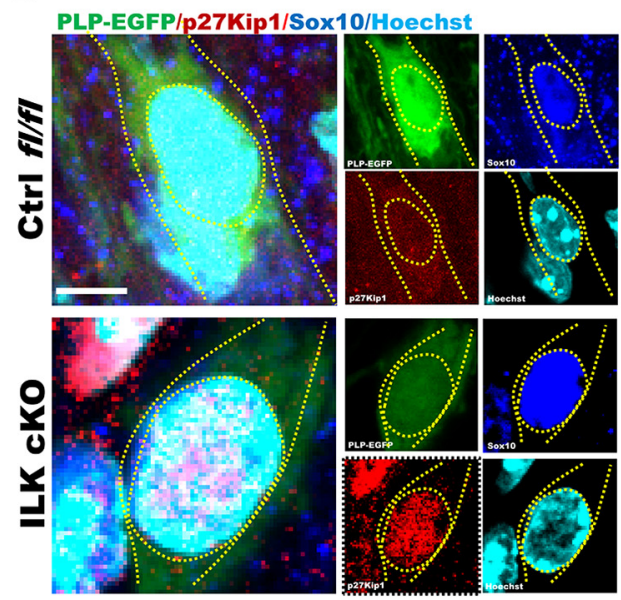

Figure 12. Deletion of ILK upregulated p27kip1 in oligodendrocytes. Control and cK0 cerebrum was analyzed for expression of p27kip1, which was dramatically upregulated in the tissue (A, $B$ ) (unpaired $t$-test). When control and $C K 0$ samples carrying the PLP-EGFP transgene were investigated by immunofluorescence, p27kip1 expression (red) was clearly upregulated in the nucleus of Sox10 (blue)/PLP-EGFP-positive cells (C, D). $N=6$ mice. Scale bars: $C, 50 \mu \mathrm{m} ; \boldsymbol{D}, 5 \mu \mathrm{m}$.

Intriguingly, in vivo, myelin was thinner in the corpus callosum, but not in the spinal cord, indicating that ILK deletion in the corpus callosum did affect myelin thickness, but in spinal cord it did not. Conversely, there were clearly fewer oligodendrocytes present and fewer axons were myelinated in both the corpus callosum and spinal cord (Figs. 2, 3, 7, 8). These studies suggest that later stages of CNS myelination may be less dependent on ILK than early stages of OPC production and differentiation. This is consistent with studies by O'Meara et al. (2013), who analyzed optic nerve myelination after ILK deletion from PLP-expressing postnatal oligodendrocytes and reported a decrease in the percentage of myelinated axons at P14. In particular, early postnatal tamoxifen-induced ILK deletion in PLP-CreERT-expressing OPCs caused a reduction in optic nerve myelination at $\mathrm{P} 14$; however, there was recovery of normal myelination by P28 (O'Meara et al., 2013). Interestingly, in contrast to the current studies, in that study, no change in the number of OPCs or mature oligodendrocytes was found in any area of the brain. They had also seen significant changes in oligodendrocyte development in vitro in the absence of ILK, but noted that oligodendrocyte development in vivo in the absence of ILK was phenotypically more normal than in vitro. The current studies would suggest that ILK loss in this lineage affects differentiation, but both these studies and those of O'Meara et al. (2013) indicate that, once cells start to myelinate, ILK loss does not have a dramatic impact on myelinating oligodendrocytes per se, although fewer axons are myelinated and myelin is thinner, at least in corpus callosum.

\section{ILK deletion in Olig1-expressing cells affects \\ OPC development}

Unexpectedly, whereas ILK-deficient oligodendrocytes can generate compact myelin and, in spinal cord, can even generate compact myelin of normal thickness, ILK loss in Olig1positive cells had a far greater impact by reducing OPC production. Clearly, OPCs are dependent on ILK in the transition from quiescent to active proliferation and deletion of ILK reduced the number of oligodendrocyte lineage cells. In corpus callosum from P0-P30 ILK cKO mice, there was up to a $50 \%$ reduction in the number of Olig2 + cells relative to age-matched littermates, with an apparent decrease in Olig2 expression per cell. All cells in the lineage were reduced, starting with the early Sox2-positive progenitor cells, which likely led to the reduction in NG2-positive OPCs, CC1-positive mature cells, and PLP-EGFP-positive cells at P0 and P10. However, the most deficient population of cells was the CC1positive mature oligodendrocytes (Figs. 3, 7), which suggests not only an impact on the early stages of the lineage, but an additional impact on differentiation. 


\section{ILK loss reduced the pool of OPCs by altering proliferation dynamics}

Oligodendrocyte lineage-specific ablation of ILK downregulated several cell cycle drivers significantly and there was a dramatic increase in the cell cycle inhibitory protein p27Kip1. Silencing ILK function in numerous cancer cells has been shown to suppress their proliferation and induce apoptosis. ILK overexpression elevates cyclin D1 protein levels and induces the cyclin D1 gene directly in mammary epithelial cells. Inhibition of PI3K and $\mathrm{AKT} /$ protein kinase B reduces ILK induction of cyclin D1 expression (D'Amico et al., 2000). Further ILK activation of the cyclin D1 promoter is abolished by dominant-negative mutants of CREB (D'Amico et al., 2000). ILK overexpression results in increased expression of cyclin D1 and activation of Cdk4 and cyclin E-associated kinases, along with increased expression of p21 and p27 Cdk inhibitors, with the p27 from ILK-overexpressing cells having reduced inhibitory activity. Therefore, ILK induces signaling pathways, resulting in the stimulation of G1/S cyclin-Cdk activities, which are normally regulated by cell adhesion and integrin engagement (Radeva et al., 1997). Moreover, ILK activity is constitutively elevated in a serum- and anchorage-independent manner in PTEN-mutant prostate carcinoma cell lines. Furthermore, dominant-negative ILK induces $G_{1}$ phase cycle arrest and enhanced apoptosis (Persad et al., 2000). The current studies are consistent with the conclusion that this impact on the cell cycle is a major role of ILK in the oligodendrocyte lineage as well.

In summary, ILK regulates OPC proliferation, the transition to mature oligodendrocytes, and, to some extent, myelination. The multidimensional nature of this regulation affects both the cell cycle and cell differentiation. Its impact on the cytoskeleton appears less relevant to oligodendrocyte development to mature myelinating cells and ILK appears more relevant to OPC proliferation and their early differentiation.

\section{References}

Ahrendsen JT, Macklin W (2013) Signaling mechanisms regulating myelination in the central nervous system. Neurosci Bull 29:199-215. CrossRef Medline

Bercury KK, Macklin WB (2015) Dynamics and mechanisms of CNS myelination. Dev Cell 32:447-458. CrossRef Medline

Berken A, Abel J, Unfried K (2003) betal-integrin mediates asbestosinduced phosphorylation of AKT and ERK1/2 in a rat pleural mesothelial cell line. Oncogene 22:8524-8528. Medline

Bujalka H, Koenning M, Jackson S, Perreau VM, Pope B, Hay CM, Mitew S, Hill AF, Lu QR, Wegner M, Srinivasan R, Svaren J, Willingham M, Barres BA, Emery B (2013) MYRF is a membrane-associated transcription factor that autoproteolytically cleaves to directly activate myelin genes. PLoS Biol 11:e1001625. CrossRef Medline

Chiswell BP, Zhang R, Murphy JW, Boggon TJ, Calderwood DA (2008) The structural basis of integrin-linked kinase-PINCH interactions. Proc Natl Acad Sci U S A 105:20677-20682. CrossRef Medline

Chun SJ, Rasband MN, Sidman RL, Habib AA, Vartanian T (2003) Integrinlinked kinase is required for laminin-2-induced oligodendrocyte cell spreading and CNS myelination. J Cell Biol 163:397-408. CrossRef Medline

Colognato H, Tzvetanova ID (2011) Glia unglued: how signals from the extracellular matrix regulate the development of myelinating glia. Dev Neurobiol 71:924-955. CrossRef Medline

Dagnino L (2011) Integrin-linked kinase: a Scaffold protein unique among its ilk. J Cell Commun Signal 5:81-83. CrossRef Medline

Dai J, Bercury KK, Macklin WB (2014) Interaction of mTOR and Erk1/2 signaling to regulate oligodendrocyte differentiation. Glia 62:2096-2109. CrossRef Medline

D'Amico M, Hulit J, Amanatullah DF, Zafonte BT, Albanese C, Bouzahzah B, Fu M, Augenlicht LH, Donehower LA, Takemaru K, Moon RT, Davis R, Lisanti-MP, Shtutman M, Zhurinsky J, Ben-Ze'ev A, Troussard AA, Dedhar S, Pestell RG (2000) The integrin-linked kinase regulates the cyclin
D1 gene through glycogen synthase kinase 3beta and cAMP-responsive element-binding protein-dependent pathways. J Biol Chem 275:32649 32657. CrossRef Medline

Emery B (2010) Regulation of oligodendrocyte differentiation and myelination. Science 330:779-782. CrossRef Medline

Emery B, Agalliu D, Cahoy JD, Watkins TA, Dugas JC, Mulinyawe SB, Ibrahim A, Ligon KL, Rowitch DH, Barres BA (2009) Myelin gene regulatory factor is a critical transcriptional regulator required for CNS myelination. Cell 138:172-185. CrossRef Medline

Fielding AB, Lim S, Montgomery K, Dobreva I, Dedhar S (2011) A critical role of integrin-linked kinase, ch-TOG and TACC3 in centrosome clustering in cancer cells. Oncogene 30:521-534. CrossRef Medline

Fields RD (2015) A new mechanism of nervous system plasticity: activitydependent myelination. Nat Rev Neurosci 16:756-767. CrossRef Medline

Flores AI, Narayanan SP, Morse EN, Shick HE, Yin X, Kidd G, Avila RL, Kirschner DA, Macklin WB (2008) Constitutively active Akt induces enhanced myelination in the CNS. J Neurosci 28:7174-7183. CrossRef Medline

Franklin RJ, ffrench-Constant C, Edgar JM, Smith KJ (2012) Neuroprotection and repair in multiple sclerosis. Nat Rev Neurol 8:624-634. CrossRef Medline

Gaesser JM, Fyffe-Maricich SL (2016) Intracellular signaling pathway regulation of myelination and remyelination in the CNS. Exp Neurol 283:501511. CrossRef Medline

Grashoff C, Aszódi A, Sakai T, Hunziker EB, Fässler R (2003) Integrinlinked kinase regulates chondrocyte shape and proliferation. EMBO Rep 4:432-438. CrossRef Medline

Hannigan GE, Leung-Hagesteijn C, Fitz-Gibbon L, Coppolino MG, Radeva G, Filmus J, Bell JC, Dedhar S (1996) Regulation of cell adhesion and anchorage-dependent growth by a new beta 1-integrin-linked protein kinase. Nature 379:91-96. CrossRef Medline

Hornig J, Fröb F, Vogl MR, Hermans-Borgmeyer I, Tamm ER, Wegner M (2013) The transcription factors Sox 10 and Myrf define an essential regulatory network module in differentiating oligodendrocytes. PLoS Genet 9:e1003907. CrossRef Medline

Koul D, Shen R, Bergh S, Lu Y, de Groot JF, Liu TJ, Mills GB, Yung WK (2005) Targeting integrin-linked kinase inhibits Akt signaling pathways and decreases tumor progression of human glioblastoma. Mol Cancer Ther 4:1681-1688. CrossRef Medline

Lu QR, Sun T, Zhu Z, Ma N, Garcia M, Stiles CD, Rowitch DH (2002) Common developmental requirement for Olig function indicates a motor neuron/oligodendrocyte connection. Cell 109:75-86. CrossRef Medline

Mallon BS, Shick HE, Kidd GJ, Macklin WB (2002) Proteolipid promoter activity distinguishes two populations of NG2-positive cells throughout neonatal cortical development. J Neurosci 22:876-885. Medline

McDonald PC, Fielding AB, Dedhar S (2008a) Integrin-linked kinase-essential roles in physiology and cancer biology. J Cell Sci 121:3121-3132. CrossRef Medline

McDonald PC, Oloumi A, Mills J, Dobreva I, Maidan M, Gray V, Wederell ED, Bally MB, Foster LJ, Dedhar S (2008b) Rictor and integrin-linked kinase interact and regulate Akt phosphorylation and cancer cell survival. Cancer Res 68:1618-1624. CrossRef Medline

McKenzie IA, Ohayon D, Li H, de Faria JP, Emery B, Tohyama K, Richardson WD (2014) Motor skill learning requires active central myelination. Science 346:318-322. CrossRef Medline

Michalski JP, Cummings SE, O’Meara RW, Kothary R (2016) Integrinlinked kinase regulates oligodendrocyte cytoskeleton, growth cone, and adhesion dynamics. J Neurochem 136:536-549. CrossRef Medline

Nave KA (2010) Myelination and the trophic support of long axons. Nat Rev Neurosci 11:275-283. CrossRef Medline

Norrmén C, Suter U (2013) Akt/mTOR signalling in myelination. Biochem Soc Trans 41:944-950. CrossRef Medline

Novak A, Dedhar S (1999) Signaling through beta-catenin and Lef/Tcf. Cell Mol Life Sci 56:523-537. CrossRef Medline

Okamura M, Yamaji S, Nagashima Y, Nishikawa M, Yoshimoto N, Kido Y, Iemoto Y, Aoki I, Ishigatsubo Y (2007) Prognostic value of integrin beta1-ILK-pAkt signaling pathway in non-small cell lung cancer. Hum Pathol 38:1081-1091. CrossRef Medline

O’Meara RW, Michalski JP, Anderson C, Bhanot K, Rippstein P, Kothary R (2013) Integrin-linked kinase regulates process extension in oligodendrocytes via control of actin cytoskeletal dynamics. J Neurosci 33:97819793. CrossRef Medline 
Pereira JA, Benninger Y, Baumann R, Gonçalves AF, Ozçelik M, Thurnherr T, Tricaud N, Meijer D, Fassler R, Suter U, Relvas JB (2009) Integrinlinked kinase is required for radial sorting of axons and Schwann cell remyelination in the peripheral nervous system. J Cell Biol 185:147-161. CrossRef Medline

Persad S, Attwell S, Gray V, Delcommenne M, Troussard A, Sanghera J, Dedhar S (2000) Inhibition of integrin-linked kinase (ILK) suppresses activation of protein kinase B/Akt and induces cell cycle arrest and apoptosis of PTEN-mutant prostate cancer cells. Proc Natl Acad Sci U S A 97:3207-3212. CrossRef Medline

Radeva G, Petrocelli T, Behrend E, Leung-Hagesteijn C, Filmus J, Slingerland J, Dedhar S (1997) Overexpression of the integrin-linked kinase promotes anchorage-independent cell cycle progression. J Biol Chem 272: 13937-13944. CrossRef Medline

Silbereis JC, Nobuta H, Tsai HH, Heine VM, McKinsey GL, Meijer DH, Howard MA, Petryniak MA, Potter GB, Alberta JA, Baraban SC, Stiles CD, Rubenstein JL, Rowitch DH (2014) Olig1 function is required to repress $\mathrm{dlx} 1 / 2$ and interneuron production in mammalian brain. Neuron 81:574-587. CrossRef Medline

Smeeton J, Zhang X, Bulus N, Mernaugh G, Lange A, Karner CM, Carroll TJ, Fässler R, Pozzi A, Rosenblum ND, Zent R (2010) Integrin-linked kinase regulates p38 MAPK-dependent cell cycle arrest in ureteric bud development. Development 137:3233-3243. CrossRef Medline

Troussard AA, Mawji NM, Ong C, Mui A, St-Arnaud R, Dedhar S (2003) Conditional knock-out of integrin-linked kinase demonstrates an essential role in protein kinase B/Akt activation. J Biol Chem 278:2237422378. CrossRef Medline

Tsai HH, Niu J, Munji R, Davalos D, Chang J, Zhang H, Tien AC, Kuo CJ, Chan JR, Daneman R, Fancy SP (2016) Oligodendrocyte precursors migrate along vasculature in the developing nervous system. Science 351: 379-384. CrossRef Medline
Tu Y, Huang Y, Zhang Y, Hua Y, Wu C (2001) A new focal adhesion protein that interacts with integrin-linked kinase and regulates cell adhesion and spreading. J Cell Biol 153:585-598. CrossRef Medline

Watzka SB, Setinek U, Stubenberger EB, Tötsch M, Dekan G, Marcher M, Fleck T, Müller MR (2011) Integrin-linked kinase, phosphorylated AKT and the prognosis of malignant pleural mesothelioma. Eur J Cardiothorac Surg 39:180-184. CrossRef Medline

Widmaier M, Rognoni E, Radovanac K, Azimifar SB, Fässler R (2012) Integrin-linked kinase at a glance. J Cell Sci 125:1839-1843. CrossRef Medline

Wood TL, Bercury KK, Cifelli SE, Mursch LE, Min J, Dai J, Macklin WB (2013) mTOR: a link from the extracellular milieu to transcriptional regulation of oligodendrocyte development. ASN Neuro 5:e00108. CrossRef Medline

Wu C, Dedhar S (2001) Integrin-linked kinase (ILK) and its interactors: a new paradigm for the coupling of extracellular matrix to actin cytoskeleton and signaling complexes. J Cell Biol 155:505-510. CrossRef Medline

Xie W, Zhao M, Zhou W, Guo L, Huang L, Yu W, Li X (2013) Targeting of integrin-linked kinase with small interfering RNA inhibits VEGFinduced angiogenesis in retinal endothelial cells. Ophthalmic Res 49: 139-149. CrossRef Medline

Yu Y, Chen Y, Kim B, Wang H, Zhao C, He X, Liu L, Liu W, Wu LM, Mao M, Chan JR, Wu J, Lu QR (2013) Olig2 targets chromatin remodelers to enhancers to initiate oligodendrocyte differentiation. Cell 152:248-261. CrossRef Medline

Zhu X, Zuo H, Maher BJ, Serwanski DR, LoTurco JJ, Lu QR, Nishiyama A (2012) Olig2-dependent developmental fate switch of NG2 cells. Development 139:2299-2307. CrossRef Medline

Zuchero JB, Barres BA (2013) Intrinsic and extrinsic control of oligodendrocyte development. Curr Opin Neurobiol 23:914-920. CrossRef Medline 